\title{
PROCESSO DE ETNODEMOCRATIZAÇÃO: AS (IN)CONGRUÊNCIAS ENTRE AS DEMANDAS E AS PROPOSIÇÕES LEGISLATIVAS SOBRE "INDÍGENAS" (1988-2020)
}

\author{
THE PROCESS OF ETHNODEMOCRATIZATION: THE (IN)CONGRUENCES BETWEEN THE \\ DEMANDS AND THE LEGISLATIVE PROPOSALS ABOUT "INDIGENOUS" (1988-2020)
}

\section{Antonio Armando Ulian do Lago Albuquerque}

Professor efetivo da Universidade Federal do Sul da Bahia (UFSB) e Universidade do Estado de Mato Grosso (UNEMAT). Mestre em Direito pela UFSC (CAPES 6), Doutor em Ciência Política pelo IESP-UERJ (CAPES 6).

E-mail: lagoalbuquerque@ hotmail.com

Recebido em: 03/05/2020

Aprovado em: 16/10/2020

RESUMO: O artigo objetiva correlacionar as diretrizes e categorias da Conferência Nacional de Política Indigenista (CONPI) com o conteúdo das proposições legislativas da Câmara Federal, do Brasil, apontando as congruências e incongruências entre ambas. Utiliza-se a dedução com técnica de pesquisa de análise de conteúdo para compor as unidades de análise e avaliar a congruência ou não entre as medidas, possibilitando situar a atuação política indígena em relação ao processo de etnodemocratização. $\mathrm{O}$ substrato teórico funda-se nas teorias políticas democráticas que investigam a participação como variável a influenciar a representação política, seja para corrigi-la, fortalecêla ou subsidiar conteúdo para a criação de proposições legislativas. Espera-se como resultado confirmar a hipótese de maior congruência entre as demandas indígenas e as proposições favorecem o processo de etnodemocratização.

Palavras-chave: Democracia. Povos indígenas. Representação. Participação. Etnodemocratização

\begin{abstract}
The article aims to correlate the guidelines and the categories from the on Indigenous Policy National Conference (CNPI) with the content about the legislative proposals of the Federal Camara, from Brazil, pointing out the congruences and the incongruences between both. Deduction with a content analysis research technique is used to compose the units of analysis to evaluate the congruence or not around the measures, making it possible to situate the indigenous political acting in relation to the process of ethnodemocratization. The theoretical substrate is based on democratic political theories which investigate the participation as a variable that influences the political representation, being to correct or to subsidize the the content for the elaboration of the legislative proposals. As a result, it is expected to confirm the hypothesis that the greater congruence between the indigenous demands and the proposals to support the process of ethnodemocratization.
\end{abstract}

Keywords: Democracy. Indian people. Representation. Participation. 
SUMÁRIO: Introdução; 1. Mapeando as demandas indígenas nas Conferências Nacionais de Políticas Públicas (CNPPs): o que querem os povos originários?; 2. Proposições normativas sobre indígenas: o que não quer o Executivo e o Legislativo; Conclusão; Referências.

\section{INTRODUÇÃO}

$\mathrm{O}$ artigo se propõe a correlacionar as diretrizes da participação indígena na Conferência Nacional de Política Indigenista (CONPI) com as proposições legislativas - Projetos de Lei Ordinárias (PLs), Projetos de Leis Complementares (PLPs), Propostas de Emendas à Constituição (PECs) e Propostas de Medidas Provisórias (MPVs) - para avaliar a congruência e a incongruência de sentidos entre os conteúdos da participação e representação sobre "indígenas". Por um lado, maior congruência entre ambas aponta para um processo de etnodemocratização. Ou seja, que as instituições democráticas pluralizam a execução de políticas públicas, considerando povos indígenas de modo homogêneo ou heterogêneo. Por outro lado, maior incongruência aponta menor possibilidade de etnodemocratização das instituições e, consequentemente, maior exclusão dos povos indígenas.

O processo de etnodemocratização pode ocorrer tanto em relação a criação de políticas a estabelecerem medidas para todas as etnias indígenas (etnodemocratização homogênea) ou por meio de proposições reconhecedoras da plurietnicidade (etnodemocratização pluralista).

$\mathrm{O}$ reconhecimento normativo representa apenas parte da realidade. A ineficácia das normas (Ferrajoli) garantidoras das terras indígenas tem evidenciado não bastar a vigência e a validade das normas jurídicas referentes aos "indígenas", pois a interpretação jurídica comumente desvia o sentido público de afirmação identitária associada a terra indígena, para garantirem o sentido econômico-financeiro privatista de propriedade. A Constituição Federal, no art. 231 e 232, combinada com o Decreto n. 5.051/2004, e demais legislação infraconstitucional protetiva do meio ambiente e da diversidade cultural, possibilitam outras interpretações (ALBUQUERQUE, 2019). Este artigo se subsidiará nas pesquisas que tenham por objeto o estudo da relação entre os espaços participativos e a representação eleitoral nas democracias contemporâneas.

Metodologicamente pautar-se-á por análise dedutiva com a utilização de técnica de pesquisa de análise de conteúdo, com formação de unidades de análise, qualitativa, a partir a) dos documentos finais das Conferências Nacionais de Políticas Públicas (CNPPs) e b) das ementas e inteiro teor das proposições legislativas (1988-2020).

A diluição dos dados quantitativos (proposições de leis e demandas sobre indígenas) comparados ao universo obstaria definir o grau de ocorrência de demandas e proposições sobre "indígenas" que possam evidenciar um processo de etnodemocratização em curso. É o recorte da especificidade plueriétnica e cultural que oportuniza avaliar este processo. Este artigo tenta cumprir com pesquisa apenas com o aspecto da diversidade cultural indígena e compreende ser parcial, necessitando da criação de uma agenda de pesquisa sobre a correlação entre as demandas dos espaços públicos com as proposições legislativas referentes aos povos tradicionais, quilombolas e demais "minorias".

A abordagem da pesquisa ao diminuir a importância da comparação entre a densidade demográfica indígena e não-indígena, em relação às categorias participação e proposições legislativas, enfatiza a densidade cultural, considerando positivamente a influência dos povos indígenas na construção do país desde o processo colonial, tendo maior ou menor inserção política, maior ou menor reconhecimento político-jurídico e efetividade de ações governamentais. Os países de trajetória colonialista (com diversidade cultural) possuem densidade cultural maior ou menor que podem se tornar clivagens para a criação de novas instituições democráticas ou para abordagens multiculturais, por meio de partidos políticos ou de suas entidades representativas (organizações e movimentos). 
No levantamento de dados consideramos todos os documentos finais das CNPPs (19882019) (indígenas e não-indígenas) que apresentaram diretrizes vinculadas ao unitermo "indígenas". Comparativamente foram analisadas todas as categorias da CNPI a partir do conjunto de categorias das CNPPs, reclassificando-as pela recorrência de assuntos e agregando-as, tanto em relação às conferências anteriores à CNPI (2015), como posteriores, derivando quinze novas unidades de análises das 09 categorias originais da Conferência Nacional de Política Indigenista (BRASIL, 2016), conforme Tabela 1 e Figura 2.

A partir das 15 novas unidades de análise da CNPI buscou-se dentre as nove originais categorias todas as diretrizes que comportariam se inserir nas novas unidades. A Tabela 1 indica $o$ desdobramento, o que tornou possível estimar a frequência com que em cada uma das nove categorias originais apareceram diretrizes-categorias referentes às novas unidades de análise (ver Figura 3).

A nova categoria "ações governamentais indigenistas", por exemplo, compreendeu diretrizes de 8 categorias originais, tendo recorrência em quase todas as categorias da CNPI, enquanto "terras indígenas e territorialidades" tiveram recorrência em 3 categorias originais.

$\mathrm{Na}$ categoria "terras indígenas e territorialidade", por exemplo, foram agregadas as categorias de outras conferências nacionais: demarcação, fortalecimento da agricultura familiar e agroecologia, reforma agrária e democratização do acesso à terra e aos recursos naturais, direito à terra e ao território e a vulnerabilização de grupos sociais rurais, territorialidade e o direito territorial dos povos indígenas, território e mobilidade, ATER e o desenvolvimento rural, ATER para a diversidade da agricultura familiar e a redução das desigualdades, gestão, financiamento, demanda e oferta dos serviços de ATER, metodologias e abordagens de extensão rural.

Tabela 1 Desdobramento das categorias da CNPI em novas unidades de análise

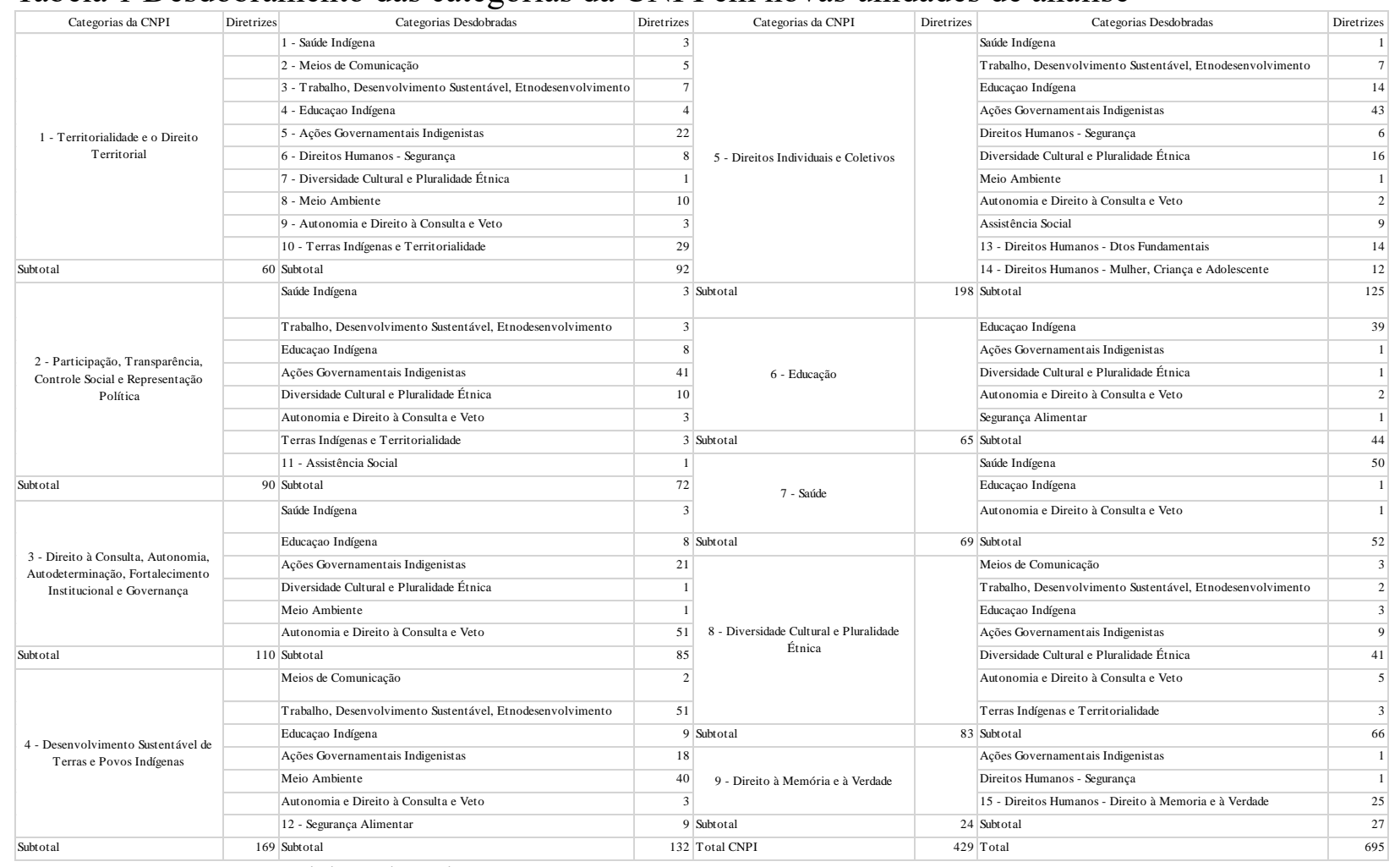

Fonte: BRASIL, 2016. Elaborado pelo Autor.

O desdobramento das categorias da CNPI possibilitou construir uma escala de 0 a 9 (máximo de categorias da CNPI) de frequência com que as novas unidades e diretrizes foram reagrupadas em razão das categorias e diretrizes originárias. A partir da Tabela 1 definiu-se os 
seguintes valores: 5 para aquelas categorias que se repetiram entre 9 e 8 vezes nas 9 (nove) categorias originais; 4 para 7 e 6 vezes; 3 para 5 e 4 vezes; 2 para 3 e 2 vezes; 1 para 1 e 0 vezes. Maior frequência aponta a maior recorrência de discussões sobre os assuntos pautados pelos povos indígenas na CNPI. A Figura 3 possibilita às lideranças e movimentos indígenas situarem as articulações e os argumentos em posteriores processos participativos, a fim de fortalecerem suas estratégias e ações.

Nesta pesquisa, as unidades de análises de conteúdo foram construídas a partir das frases que compõem as diretrizes em cada categoria, considerando a construção do sentido completo, subsumindo-as até constituir um sentido homogêneo distintivo das demais unidades.

O levantamento de dados das proposições legislativas foi realizado no site da Câmara Federal a partir de "pesquisa avançada", no período de 05 de março de 1988 a 20 de abril de 2020, utilizando-se a palavra "indígenas" no espaço assunto, selecionando os tipos de proposições em "projetos de lei ordinárias (PLs)", "propostas de emenda à Constituição (PECs)", "projetos de lei complementar (PLPs)" e "medidas provisórias (MPVs)". O conteúdo das proposições foi analisado a partir da ementa e do inteiro teor de cada tipo normativo, elaborando tabelas constando a ementa, unidade federativa, autoria, data de apresentação, partido político e situação da proposição.

A pertinência temática entre as categorias/diretrizes da CNPI e o conteúdo das proposições legislativas foi analisada a partir da congruência $(+)$ ou incongruência (-) entre os sentidos atribuídos pelos povos indígenas nas suas demandas e os sentidos expressos no inteiro teor de cada proposição legislativa. Congruentes $(+)$ foram consideradas todas as proposições com o mesmo sentido manifestado nas diretrizes da CNPI. Incongruentes (-), todos os conteúdos das proposições (inteiro teor) discordantes das diretrizes. Os dados também oportunizaram apresentar a vinculação partidária dos autores das proposições legislativas, diferenciando-os entre iniciativas do executivo e do legislativo, bem como suas associações ideológicas.

Em períodos eleitorais a análise qualitativa desses dados assume relevância, tanto para a formação de uma coalizão de representações (no âmbito municipal, regional e federal), traduzindo uma frente ampla em defesa da implantação de uma política pública indigenista, como para visibilizar os partidos e períodos governamentais com maior sensibilidade às demandas indígenas.

Primeiramente, o artigo apresenta o que querem os povos indígenas a partir das diretrizes enunciadas na Conferência Nacional de Política Indigenista (CNPI), mapeando as reivindicações de criação e execução de políticas públicas. Posteriormente, analisa-se o conteúdo das proposições legislativas correlacionando-os às diretrizes da CNPI, avaliando a congruência e a incongruência das medidas enunciadas. Espera-se, com o resultado da pesquisa esclarecer e evidenciar o processo de etnodemocratização, viabilizando aos povos indígenas situar as principais estratégias e ações políticas para reverter a sub-representação política e conquistar maior autonomia no âmbito de seus territórios.

\section{MAPEANDO AS DEMANDAS INDÍGENAS NAS CONFERENCIAS NACIONAIS DE POLÍTICAS PÚBLICAS (CNPPS): O QUE QUEREM OS POVOS ORIGINÁRIOS?}

Desde a Constituição Federal de 1934 são garantidos direitos aos povos indígenas (CUNHA, 1987; SANTOS, 1989), mas o sentido multicultural aplicado ao direito é inovação possível apenas com a Constituição de 1988. O decreto n. 5.051/2004 incluiu o princípio da autodeterminação dos povos indígenas na ordem jurídica, devendo ser cotejado em conjunto aos art. 231 e 232 da Constituição (1988) para formar uma matriz interpretativa a respeito dos povos indígenas. Trata-se de inclusão principiológica fundamental a orientar as proposições normativas

\footnotetext{
${ }^{1}$ No site da Câmara Federal, do Brasil, está disponível tanto a pesquisa simples como a pesquisa avançada de todas as proposições legislativas, podendo filtrá-las de acordo com o tipo de proposição, número, órgão, situação, assunto, autor, relator e tramitação. Disponível em: <https://www.camara.leg.br/buscaProposicoesWeb/pesquisaAvancada>. Acesso: 9 out. 2020.
} 
do estado brasileiro referentes aos povos indígenas. (ALBUQUERQUE, 2003, 2008; DUPRAT, 2015)

A realização de quaisquer atividades (pública ou privada) que possam afetar os povos indígenas exige o consentimento livre e esclarecido, a participação da comunidade em todas as fases de implementação das ações tanto nas suas próprias terras como nos territórios adjacentes.

As iniciativas governamentais, comumente, impulsionam empreendimentos que utilizam os recursos naturais em terras adjacentes aos territórios indígenas. São programas de desenvolvimento, por exemplo, geradores de hidrelétricas, mineradoras, hidrovias, ferroviais e rodovias que, comumente, impactam diretamente as terras indígenas (TIs) (PACs - Projetos de Aceleração do Crescimento, caso Belo Monte). A ausência de esclarecimento, anuência e participação pluriétnica indígena contraria a Constituição (1988) e o decreto n. 5.051/2004.

Por um lado, os povos indígenas quando recusam esses tipos de programas projetam alternativas diferentes na relação com o ambiente, porque associam ao desenvolvimento suas especificidades a fim de futuras gerações também usufruírem dos recursos naturais. Por outro, ao serem desprezados como sujeitos históricos, partícipes das decisões que os afetem, têm seus territórios degradados, diminuindo-lhes as chances de subsistência e transmissão intergeracional. Considerar os diferentes modos de relação dos povos originários com a sociedade envolvente, conhecimentos, tecnologias, cosmogonias e seus usos territoriais provoca nas democracias a elaboração e a inclusão de políticas pautadas na participação pluriétnica desses povos: um processo de etnodemocratização da democracia. (ALBUQUERQUE, 2015, 2019) A participação política indígena nos espaços públicos deliberativos (assembleias, conselhos e conferências) tem sido indicativa dessa reorientação.

As CNPPs possuem característica consultiva e deliberativa, mas não obriga o governo a observar suas diretrizes finais, embora sejam reconhecidas como referenciais no desenvolvimento de políticas públicas, principalmente pelo amplo processo participativo em escala local, regional e nacional. (POGREBINSCHI, 2010; AVRITZER, 2014)

As diretrizes, embora não vinculantes, influenciam não apenas a iniciativa de leis como a sua correção, principalmente ao inexistir informações suficientes a respeito do assunto a ser legislado. As CNPPS provocam ampliação do sentido de representatividade e maior capacidade de criação de políticas vinculadas aos anseios dos interessados (CAMERON, HERSHBERG, SHARPE; 2012). Experiências de práticas participativas não comprometem a política representativa das instituições democráticas, podem na verdade fortalecê-las e complementá-las (POGREBINSCHI; SAMUELS, 2014; POGREBINSCHI, VENTURA, 2017).

Ao classificar os dados das CNPPs de acordo com as sucessivas gestões governamentais, desde 1988, houve maior concentração de diretrizes durante o governo Lula e Dilma, com 91,6\% de demandas indígenas do total de 1931 diretrizes, conforme Figura 1. Comparadas a outros governos houve maior sensibilidade para com as demandas dos povos originários durante o governo do PT, muito embora também se realizaram várias ações estatais refratárias aos indígenas como, por exemplo, os Programas de Aceleração ao Crescimento (PACs). 
Figura 1 Quantidade de conferências, categorias e diretrizes indígenas por governo (1988-2019)

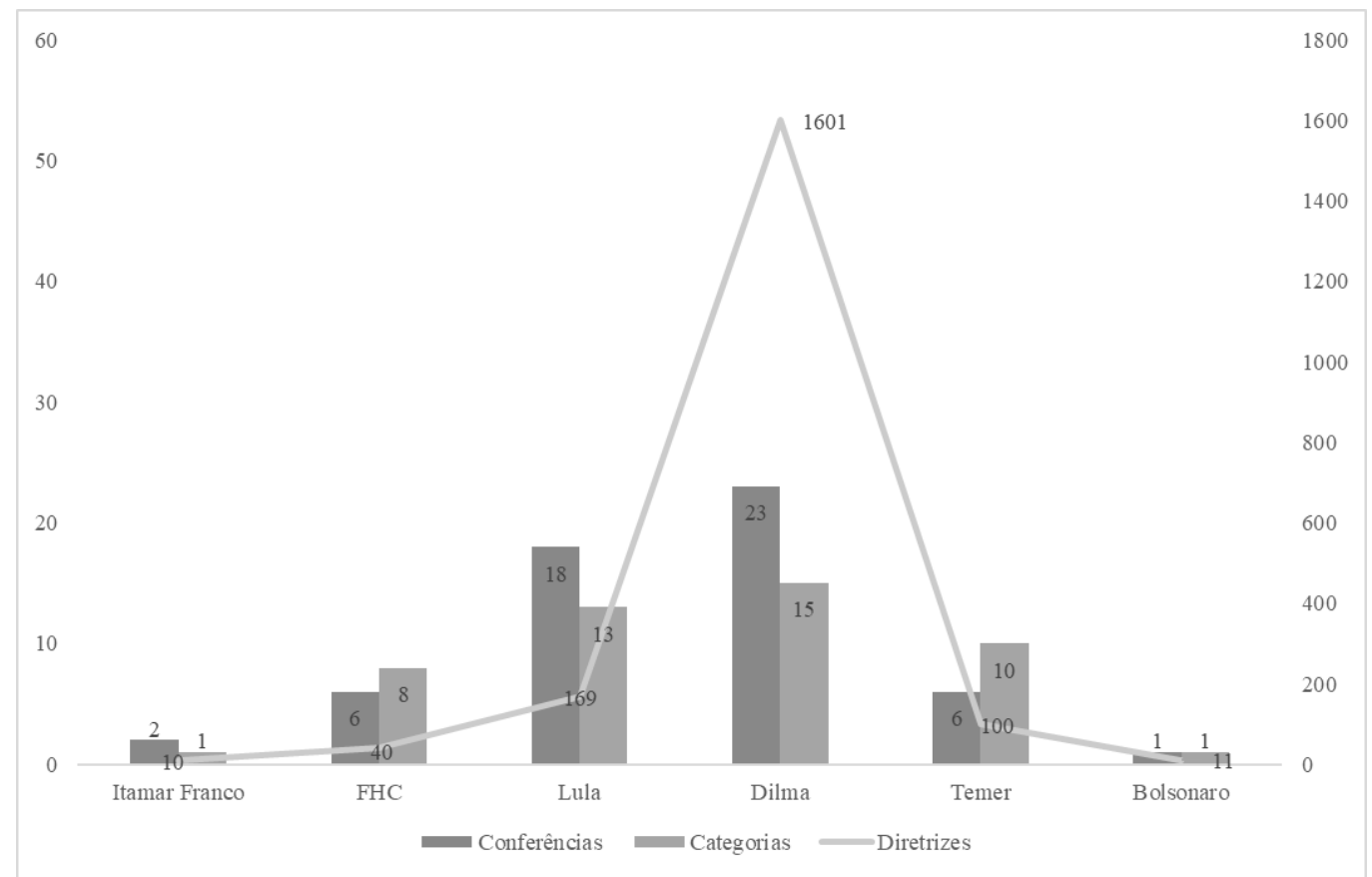

Fonte: CNPPs (1988-2019). Elaboração do autor.

Experiências participativas dos povos indígenas se tornaram frequentes desde as assembleias indígenas nos fins da década de setenta (BICALHO, 2010), e, atualmente, a elas se somaram a participação junto aos conselhos (por exemplo, saúde e educação) e às conferências nacionais. A participação nas conferências ocorre tanto nas específicas ${ }^{2}$ como também nas nãoespecíficas $^{3}$. Noutro artigo os dados apontaram maior relevância de diretrizes nas conferências não-

${ }^{2}$ II Conferência Nacional de Saúde para os Povos Indígenas (1993), III Conferência Nacional de Saúde para os Povos Indígenas (2001), IV Conferência Nacional de Saúde para os Povos Indígenas (2006), Conferência Nacional dos Povos Indígenas (2006), I Conferência Nacional de Educação Escolar Indígena (2009), $5^{\text {a }}$ Conferência Nacional de Saúde Indígena (2015), $1^{a}$ Conferência Nacional de Política Indigenista (2015).

${ }^{3}$ II Conferência Nacional de Gestão do Trabalho e Educação na Saúde (1994), Conferência Nacional de Direitos Humanos (1996), II Conferência Nacional de Direitos Humanos (1997), III Conferência Nacional de Direitos Humanos (1998), VI Conferência Nacional de Direitos Humanos (2001), VII Conferência Nacional de Direitos Humanos (2002), I Conferência Nacional do Meio Ambiente (2003), IX Conferência Nacional de Direitos Humanos (2004), I Conferência Nacional de Políticas Públicas para Mulheres (2004), I Conferência Nacional de Promoção da Igualdade Racial (2005), II Conferência Nacional do Meio Ambiente (2005), V Conferência Nacional de Assistência Social (2005), III Conferência Nacional de Segurança Alimentar e Nutricional (2007), XI Conferência Nacional de Direitos Humanos (2008), I Conferência Nacional de Desenvolvimento Rural Sustentável e Solidário (2008), I Conferência Nacional de Comunicação (2009), VII Conferência Nacional de Assistência Social (2009), II Conferência Nacional de Promoção da Igualdade Racial (2009), $4^{\mathrm{a}}$ Conferência Nacional de Ciência, Tecnologia e Inovação (2010), $2^{\mathrm{a}}$ Conferência Nacional de Cultura (2010), I Conferência Nacional de Educação (2010), 2 ${ }^{a}$ Conferência Nacional de Políticas Públicas e Direitos Humanos para LGBTs (2011), $4^{\circ}$ Conferência Nacional de Segurança Alimentar e Nutricional (2011), $8^{\circ}$ Conferência Nacional de Assistência Social (2011), 14ª Conferência Nacional de Saúde (2011), $3^{\mathrm{a}}$ Conferencia de Políticas para as Mulheres (2011), $2^{\mathrm{a}}$ Conferência Nacional de Políticas Públicas de Juventude (2011), $9^{\mathrm{a}}$ Conferência Nacional dos Direitos da Criança e do Adolescente (2012), $2^{\mathrm{a}}$ Conferência Nacional de Desenvolvimento Rural Sustentável e Solidário (2013), $9^{\circ}$ Conferência Nacional de Assistência Social (2013), $4^{\mathrm{a}}$ Conferência Nacional do Meio Ambiente (2013), $3^{\text {a }}$ Conferência Nacional de Cultura (2013), $2^{\text {a }}$ Conferência Nacional de Educação (CONAE) (2014), $5^{\text {a }}$ Conferência Nacional de Segurança Alimentar e Nutricional (2015), 10 ${ }^{\text {a }}$ Conferência Nacional de Assistência Social (2015), $3^{\text {a }}$ Conferência Nacional de Juventude: mais liberdades e democracia (2015), $2^{\mathrm{a}}$ Conferência Nacional de Assistência Técnica e Extensão Rural na Agricultura Familiar e na Reforma Agrária (2015), $3^{\text {a }}$ Conferência Nacional de Políticas Públicas de LGBT (2016), $4^{a}$ Conferência Nacional dos Direitos da Pessoa com Deficiência (2016), 10 a Conferência Nacional dos Direitos da Criança e do Adolescente (2016), 12a Conferência Nacional de Direitos Humanos: "Democracia, Justiça e Igualdade (2016), $4^{\text {a }}$ Conferência Nacional de Política para as 
específicas como, por exemplo, educação, saúde e direitos humanos. (ALBUQUERQUE, 2015) Apenas em 2016 houve a compilação dos dados da CNPI, e apontaram uma inversão não apenas da quantidade, mas da relevância das diretrizes para as conferências específicas.

Apenas a CNPI (2016) foi responsável por 45,88\% (886) do total das 1931 diretrizes indígenas. No documento final as diretrizes foram classificadas em nove categorias originais. Neste artigo foram reclassificadas para atualizá-las com as diretrizes doutras conferências ocorridas posteriormente a 2015 .

Tendo por matriz as 09 categorias originais obteve-se 15 novas categorias com 695 diretrizes distribuídas, conforme Figura 2.

Figura 2 Categorias e diretrizes da Conferência Nacional de Política Indigenista (CNPI)

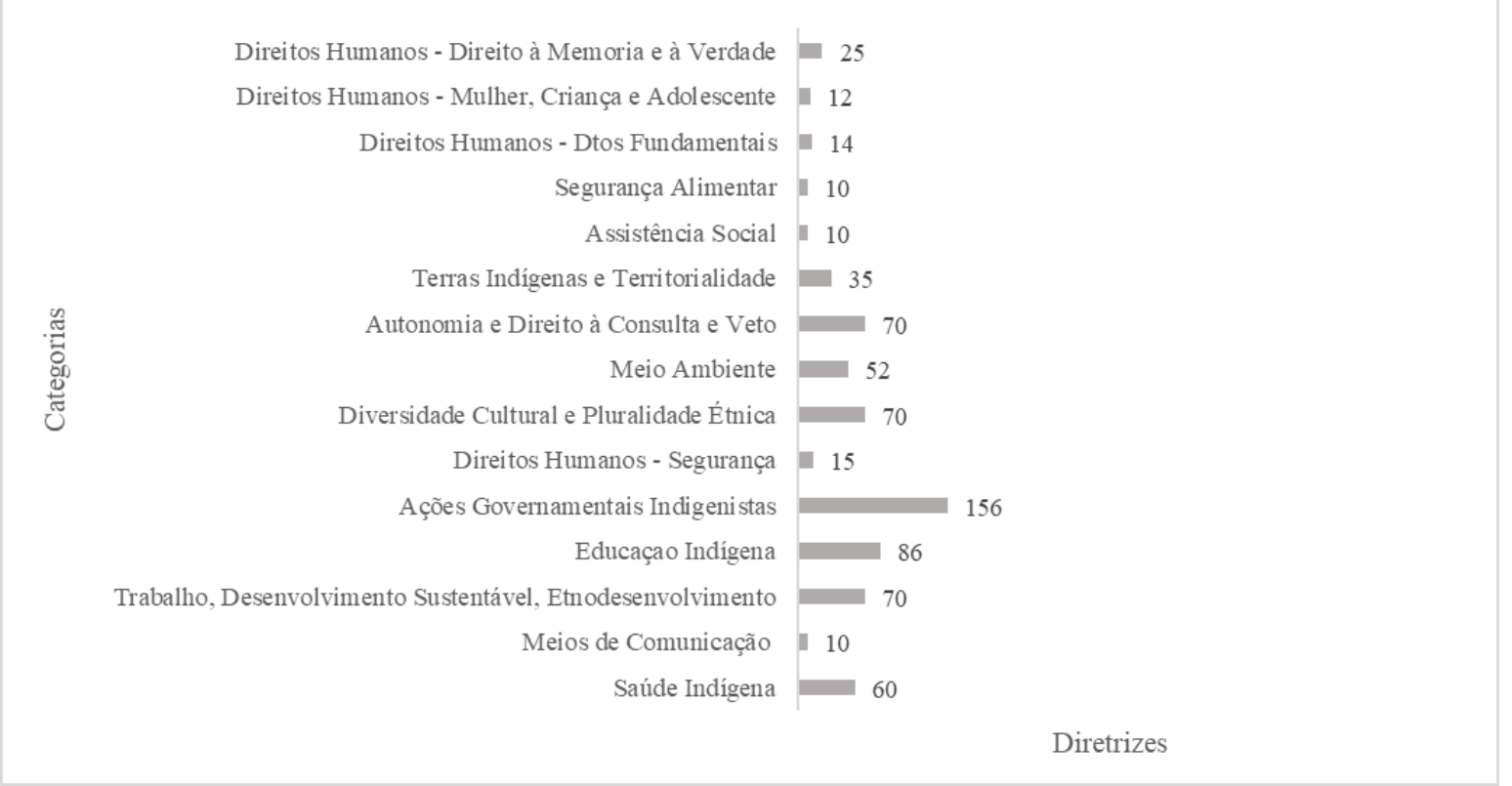

Fonte: BRASIL, 2016. Elaboração do autor.

Maior diversidade de categorias associadas às diretrizes significa pluralidade de discussões e deliberações. Com o desdobramento de dados do documento final houve diminuição da quantidade de diretrizes (886 para 695) devido a repetição das mesmas em categorias diferentes. Por outro lado, ampliaram-se as categorias (09 para 15), apontando maior ou menor convergência com as diretrizes classificadas originariamente. A partir do desdobramento formou-se a escala de recorrência para mapear as articulações e discussões levadas a efeito no processo deliberativo, conforme a Figura 3.

Se "terras indígenas e territorialidade" são considerados assuntos relevantes para as articulações políticas dos povos originários, as mobilizações em futuras discussões nas conferências precisarão multiplicar as diretrizes vinculadas a terra, inclusive para o consequente pleito de afirmação autonômica.

A clareza sobre os assuntos deliberados favorece a alteração, a manutenção ou a correção das reivindicações em outras conferências específicas - tanto a quantidade de demandas vinculadas aos problemas discutidos, como os assuntos pautados - objetivando maior coesão e instrumentalização de ações para efetivar as diretrizes.

Mulheres (2016), $2^{\text {a }}$ Conferência Nacional de Saúde da Mulher (2017), $11^{\text {a }}$ Conferência Nacional de Serviço Social (2017), 5a Conferência Nacional Infanto-Juvenil pelo Meio Ambiente (2018), 4ª Conferência Nacional de Promoção da Igualdade Racial (2018), $1^{\text {a }}$ Conferência Nacional de Vigilância em Saúde (2018), $3^{\text {a }}$ Conferência Nacional da Educação (2018), 16 ${ }^{\text {a }}$ Conferência Nacional de Saúde (2019).

Revista de Direito Brasileira | Florianópolis, SC | v. 27 | n. 10 | p.374-397 | Set./Dez. 2020 
Menor quantidade de diretrizes nas categorias como, por exemplo, "autonomia", aponta perda de oportunidade em afirmar outra e nova conjuntura de política indigenista. As conferências são momentos únicos e extremamente relevantes para elaborar o maior número de argumentos para favorecer não apenas o cumprimento das reivindicações suscitadas decorrentes dos problemas levantados, mas principalmente para recompor outras alternativas sociais e democráticas cuja centralidade resida na formação de uma rede e teia entre todos os povos diferenciados.

As deliberações da CNPI mais apontam para demandas a serem cumpridas pelo estado, e pouco indicam a possibilidade de se construir novos rearranjos institucionais democráticos. $\mathrm{O}$ fortalecimento de diretrizes associadas à "autonomia e direito à consulta e veto", em novos processos participativos e deliberativos se faz premente, porque não apenas enuncia outra conjuntura de prática política participativa, mas provoca construção democrática e pluriétnica, cuja centralidade se volte para a diversidade cultural.

Figura 3 Recorrência de categorias na Conferência Nacional de Política Indigenista (CNPI)

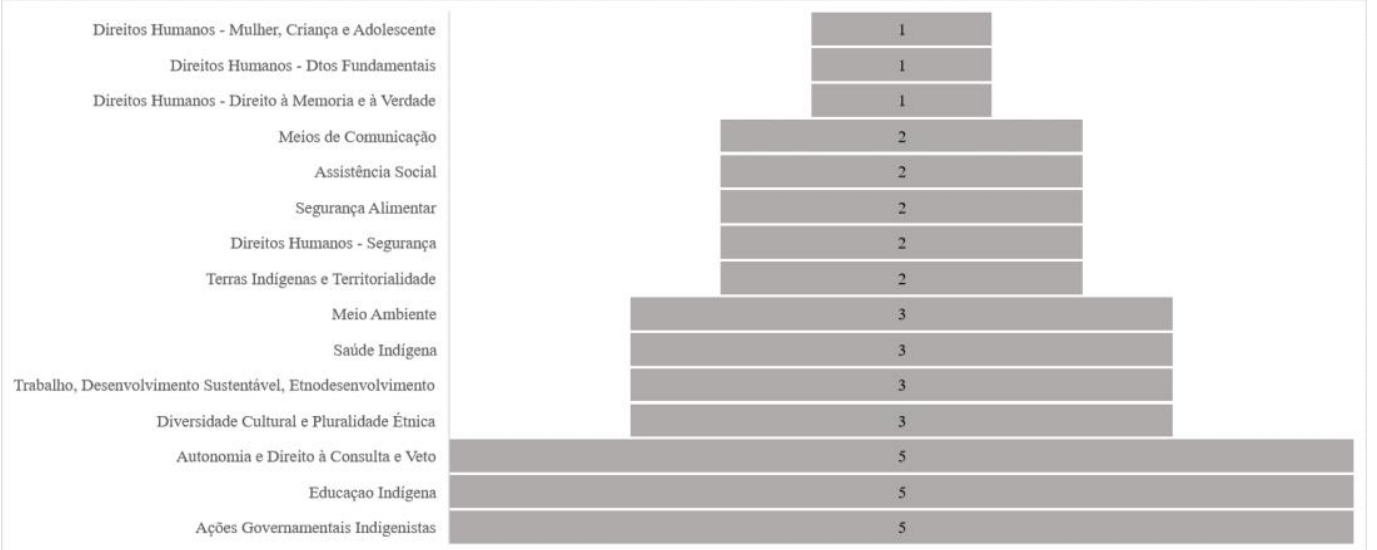

Fonte: BRASIL, 2016. Elaboração do autor.

Diretrizes associadas à categoria "terras indígenas e territorialidades" não perpassaram por todas as nove categorias iniciais, obtendo baixa recorrência. Variável que pode ter contribuído para esse índice se associa a menor força de articulação (nas conferências) das etnias que ainda não possuem suas terras devidamente demarcadas e homologadas. Obviamente que se trata de hipótese a partir das próprias diretrizes e categorias indígenas elaboradas na CNPI, ou seja, a partir da própria discursividade indígena. Entretanto, o documento final não oferece dados em relação à plurietnicidade da plenária final, dificultado analisar a hipótese de divisão entre os participantes dentre os que já possuem suas terras declaradas e aqueles que ainda a pleiteiam. Por outro lado, as principais lideranças de etnias diferentes têm sido veementes, ao longo de décadas, na defesa de demarcação das TIs a todos os povos originários, demonstrando unidade pluriétnica no discurso, bem como ações concretas em prol da conquista das TIs.

Há outras hipóteses como, por exemplo, a omissão estatal quanto ao trâmite dos procedimentos administrativos das fases de demarcação ou devido a posição partidária (representação eleitoral) refratária às declarações das TIs já identificadas, ou mesmo posição antiindígena dos governos brasileiros como, por exemplo, a Instrução Normativa n. 09, FUNAI/2020 (Jair Bolsonaro). ${ }^{4}$

\footnotetext{
${ }^{4}$ A situação das terras indígenas (ISA, 2020) aponta um total de 722 TIs, dentre as quais: 486 homologadas e reservadas (homologadas pela Presidência da República, adquiridas pela União ou doadas por terceiros), 119 em identificação (em estudo por grupo de trabalho nomeado pela FUNAI), 74 declaradas (declaradas pelo Ministro da Justiça) e 43 identificadas (relatório de estudo aprovado pela presidência da FUNAI).
} 
A recorrência entre as "ações governamentais indígenas" e a categoria "terras indígenas e territorialidades", em escalas diferentes, respectivamente 5 e $2^{5}$, enuncia aos povos originários principalmente aqueles que já possuem suas terras demarcadas - um enfrentamento unificado multicultural e pluriétnico para a satisfação de demarcação, objetivando não dividir as reivindicações entre aqueles que já possuem terras e demandam ações governamentais a cumprirem com a garantias de bem estar em seus respectivos territórios e os outros que ainda necessitam do reconhecimento de suas terras ${ }^{6}$. Acertada, neste sentido, a campanha por Demarcação Já!, mais ainda frente a governos radicalmente contrários à demarcação de TIs.

As categorias mais recorrentes na Figura 3 estão associadas às diretrizes que exigem previamente o reconhecimento de TIs. Se os anseios mais recorrentes estão a solicitar ações governamentais nos territórios já reconhecidos pode aparentar certa fragilidade da unidade pluriétnica indígena em torno das demandas de povos que ainda não possuem suas terras demarcadas. Se há alguma categoria com força política participativa a fim de unificar as reivindicações indígenas, esta é o "direito à terra" e a "autonomia e direito a consulta e veto" que só se tornam possíveis por meio da coesão de esforços de diferentes etnias, inclusive para a formação de um partido político pluriétnico.

No documento final da CNPI há várias diretrizes em relação à saúde e terras indígenas que enunciam a elevação de qualidade de vida e bem-estar nas comunidades como, por exemplo: saneamento básico com pavimentação, limpeza pública, destino do lixo industrializado, reciclagem, rede de esgoto, rede de água nos centros das regiões administrativas, captação de água por poços artesianos, cacimba, roda de bombeamento de água. (BRASIL, 2016) Essas demandas se afastam do estigma colonial de povos indígenas pré-modernos. Por outro lado, evidencia a superação do problema de demarcação das TIs para alguns povos. A solidariedade pluriétnica indígena se coloca como desafio maior a ser superado para unificar os povos em torno de outros que ainda se encontram sem suas territorialidades, inclusive superando obstáculos tradicionais interétnicos.

Sob a categoria "ações governamentais indigenistas" foram agrupadas todas as diretrizes a exigirem providências governamentais em várias atividades de interesse dos povos indígenas. São aquelas demandas não cabíveis nas demais categorias específicas, mas que se vinculam às providências estatais de ordem mais ampla, dentre as quais: arquivamento da Portaria 303 da AGU e de decretos supressores ou restritivos de direitos indígenas, acesso aos serviços estatais nas fronteiras, regulamentação do poder de polícia da FUNAI, criação do fórum permanente de discussão sobre a gestão compartilhada de TIs e Unidades de Conservação, garantia de cargos e cadeiras exclusivamente para indígenas em todos os entes federados e conselhos associados às causas indígenas.

As diretrizes sobre "educação indígena" vão desde reivindicações de estrutura em todos os níveis educacionais nas TIs, qualificação em agroecologia, economia solidária, cooperativismo, monitoramento digital, legislação ambiental, política e ampliação de políticas afirmativas para ingresso na graduação e pós-graduação, até a realização de concurso específico para professores indígenas, produção de materiais didáticos a partir dos saberes tradicionais e solicitação de implementação dos territórios etnoeducacionais.

"Autonomia, direito à consulta e ao veto" constitui categoria associada tanto com a autodeterminação dos povos indígenas, garantida pelo decreto n. 5.051/2004 como também ao direito de vetar ações que impactem, direta ou indiretamente, os povos e territórios indígenas.

\footnotetext{
${ }^{5}$ Idealmente, as deliberações deveriam se ater a inversão da escala de valores da recorrência, apontando como alicerce fundamental das reivindicações as diretrizes associadas à categoria "terras indígenas e territorialidade", da qual poderiam derivar ou desdobrar todas as demais.

${ }^{6}$ Inclusive há diretriz que reconhece essa distinção, "respeitar as diferenças da comunidade indígena, levando em consideração as TI, reservas e áreas de retomada, com devolução imediata das TIs, que garantirá o modo de ser da cultura indígena" (BRASIL, 2016). 
Autonomia no sentido do estado não tomar nenhuma providência sem a devida anuência, esclarecimento e consulta aos próprios povos interessados, pois em seus respectivos territórios podem promover todas as ações necessárias para livre se determinarem.

As diretrizes englobam desde a solicitação para se respeitar as decisões das assembleias indígenas, reconhecendo o exercício de autonomia jurídico-administrativa sobre seus territórios até a atuação indígena para avaliar os programas que afetem direta ou indiretamente suas terras e modos de vivência. Também diretrizes que objetivam: garantir o direito de veto sobre empreendimento público e privado nas TIs, autorizar ou proibir o ingresso de religiões, instituições públicas ou privadas (pesquisadores, turistas, missionários e outros) em seus territórios, criar normas e estatutos internos (pluralismo etnojurídico).

Na categoria "diversidade cultural e pluralidade étnica" foram classificadas as diretrizes associadas à "indianização" das instituições democráticas. São demandas a pluralizarem a participação dos povos originários por todas as instituições, garantindo o desenvolvimento de políticas com a oitiva de diferentes etnias. Tem-se diretrizes como: garantir a participação dos povos indígenas no Legislativo, em todos os níveis, garantir participação como conselheiros tutelares em número proporcional à população indígena do município, criar núcleo de direitos individuais e coletivos indígenas nas DPUs, criar rubrica orçamentária específica, valorizar os modos de vida pluriétnicos, oficializar as línguas maternas indígenas, exigir o uso do termo "povos originários" ou "povos indígenas", assegurar o direito de registro civil com nomes tradicionais incluindo campo específico de identificação da etnia.

"Trabalho, desenvolvimento sustentável, etnodesenvolvimento" se associa às diretrizes garantidoras da implementação de projetos e atividades reconhecedores da economia criativa e diversificada, pois etnias diferentes produzem e valoram bens de modo diferentes, desde atividades burocráticas e de segurança, como vigilância para proteção das Tis, até o cultivo agroecológico, a execução de projetos socioambientais nas aldeias, o escoamento, beneficiamento e armazenamento de produções agroindígenas e a gestão de cooperativas para a manutenção de bancos de sementes, farmácia viva e ecoturismo comunitário.

Na categoria "saúde indígena" as diretrizes dizem respeito a implantação de um sistema de saneamento básico, construção de postos de saúde e casa de apoio aos profissionais, reconhecimento de práticas tradicionais de saúde (pajés, xamãs, parteiras, curandeiros e conhecedores de ervas medicinais) a se incorporarem no subsistema de saúde indígena, criação de um programa de atenção integral à saúde da mulher indígena, estruturação de laboratório de fitoterapia para manipulação de ervas medicinais, construção e reforma das unidades básicas de saúde.

Quanto ao "meio ambiente" as diretrizes objetivam a criação de políticas públicas de proteção e recuperação das bacias hidrográficas, nascentes e matas ciliares que incidam nas TIs e seu entorno, a implantação de corredores ecológicos ou etnoambientais entre as TIs e outras áreas garantindo a reposição florestal, a elaboração e execução dos Planos de Gestão Territorial e Ambiental (PGTA), a criação de uma guarda ambiental indígena, a estruturação de coleta seletiva e reciclagem do lixo nas comunidades, a conservação ambiental, respeitando os conhecimentos de cada povo, a proteção dos conhecimentos tradicionais, criando banco de dados indígenas sobre a biodiversidade, o enfrentamento à biopirataria, à pesca predatória, à exploração madeireira e minerária em TIs.

As diretrizes agregadas sob a categoria "terras indígenas e territorialidades", além das já citadas, visam assegurar aos povos indígenas o usufruto exclusivo dos recursos naturais, hídricos e minerais nas TIs de acordo com os seus próprios planejamentos, a ser discutido no âmbito do Estatuto dos Povos Indígenas. Há várias diretrizes a exigirem a demarcação e a homologação imediata de todas as TIs e o respeito à integridade do território dos povos isolados, bem como o fortalecimento da FUNAI no acompanhamento dos processos de demarcação das TIs judicializadas, a revisão e a invalidade da tese do marco temporal pelo STF, a garantia de 
recuperação, preservação e o direito de acesso aos locais tradicionais fora das áreas demarcadas, a manutenção da atribuição exclusiva da FUNAI para identificação, delimitação e demarcação das terras e o respeito às diferenças entre os povos indígenas considerando o estado de reconhecimento das TIs.

As diretrizes de "direitos humanos - segurança" vão desde a criação de um programa específico de segurança pública para físcalização, monitoramento, proteção territorial e ambiental das TIs e seu entorno, a atuação de indígenas na segurança das aldeias, até a capacitação da Polícia Federal para atuação qualificada junto às comunidades indígenas.

Sobre "segurança alimentar" as principais reivindicações associam-se à aquisição de alimentos, para as escolas, produzidos pelas próprias comunidades, preservando os hábitos alimentares e os costumes de cada povo; à efetivação de sustentabilidade a garantir a conservação, o resgate e a preservação de sementes da agrobiodiversidade indígena, a promoção da soberania da segurança alimentar e nutricional de base agroecológica nos territórios.

Na categoria "assistência social" as diretrizes objetivam assegurar atendimento aos povos indígenas, em suas políticas e ações emergenciais diante de calamidades climáticas, assegurar políticas de transferência de renda e direitos previdenciários às especificidades e formas de organizações sociais dos povos indígenas, implantar um subsistema específico indígena no âmbito do SUAS.

Quanto aos "meios de comunicação" reivindicam a implantação de sistema de comunicação nas TIs (telefonia e internet de alta qualidade), a inclusão nas legislações do direito à concessão de meios de comunicação (TV, rádios e torres de internet) nas aldeias; o incentivo à criação de mídias alternativas comunitárias.

As diretrizes da categoria "Direitos Humanos - direito à memória e à verdade" dão ênfase às reivindicações que procuram: apurar os crimes e violações aos direitos humanos enfrentados pelos povos indígenas desde a colonização até demandas que exigem a retratação pública do governo aos crimes relatados no Relatório Figueiredo, a repatriação de todas as memórias materiais e imateriais. "Direitos Humanos - Direitos Fundamentais" é categoria em que os indígenas procuram assegurar a dignidade e a proteção dos direitos humanos, a reorientação dos registros públicos para cadastrarem a etnia e o clã nos documentos, a elaboração de processo eleitoral no território indígena, a garantia de transporte escolar fluvial e terrestre de qualidade nas TIs, a garantia de acesso à saúde, educação, segurança, informação. As diretrizes da categoria "Direitos Humanos - Mulher, Criança e Adolescente" visam criar mecanismos de denúncia, atendimento e proteção em casos de violência contra as mulheres, crianças e adolescentes indígena, revisar o ECA à luz dos direitos indígenas, políticas específicas para crianças indígenas com deficiência, assegurar as devidas punições à violência (física, psicológica e moral) contra a mulher indígena.

Se, por um lado, para além de uma discussão de classificação de categorias, essas diretrizes indicam dependência de políticas públicas estatais, por outro, não deixam de ser diferenciadas e contestativas, principalmente ao contrariarem projetos degradantes ao ambiente ou exigirem formação superior (bacharelada e licenciada) específica. Se, por um lado, inexiste afastamento do sistema econômico, por outro, há sensibilidade quanto a sustentabilidade ambiental e a produção agroecológica para as gerações futuras. Se, não cabe afirmar que os povos indígenas reivindicam outro sistema de mercado a partir de suas práticas culturais, ao menos indicam outros meios de atuação com seus recursos naturais, privilegiando a satisfação comunitária, o compartilhamento e o cuidado com a natureza e suas potencialidades.

Essa dubiedade entre a dependência de iniciativas estatais fortalecedoras das comunidades e o anseio de autonomia frente ao estado mantem-se constante em várias diretrizes. As demandas includentes representam oposição indígena à deliberada omissão e menosprezo estatal ao longo de décadas. São críticas à estratégia de extermínio e/ou controle dos povos originários, ou seja, um repertório de ação para rememorar aos governos a importância desse mosaico cultural como múltiplas possibilidades criativas de políticas heterogêneas. 
A formação educacional em todos os níveis e modalidades constitui um instrumento fundamental como estratégia a estabelecer ações multiculturais e etnodesenvolvimentistas, pois ocasiona a partir dos saberes e práticas tradicionais e indígenas, um sistema próprio e diferenciado de conhecimento a fortalecer o processo autonômico e elevar a qualidade de vida desejável por cada comunidade. (ALBUQUERQUE, et al, 2016).

A diversidade cultural e plurietnicidade indígenas influenciam mais rapidamente a transição para uma etnodemocracia pluralista, porque modifica o sentido homogêneo de política pública fundando-a na multiculturalidade crítica (MCLAREN, 1997). Ao encontro dessa abordagem solicitam, dentre as várias diretrizes, o uso da terminologia "povos indígenas" ou "povos originários", pois ambas contribuem para qualificar uma política multicultural, contemplando as singularidades dos povos, reconhecendo a pluralidade de epistemologia indígena a partir das práticas de pajelança, do partejar, da aplicação de medicina tradicional, ou seja, dos modos do bem viver indígena. Embora tão-apenas a construção de outros significantes não implique noutras possibilidades econômicas, acabam por pressionar uma redistribuição mais equânime e diferenciada, pois afirmam a diferença cultural ao reconhecer valores diferentes para bens produzidos culturalmente de modo diferente daqueles hegemonicamente homogeneizados. (ALBUQUERQUE, 2008, p. 134-136)

As reivindicações de proteção da diversidade cultural indígena incidem mais no âmbito de reconhecimento, inserção e manutenção da expressão cultural artística e linguística por todos os setores da sociedade envolvente que propriamente a inclusão como política pluricultural institucional em várias instituições. A diversidade cultural e plurietnicidade são caracteres principiológicos a serem incorporados nas instituições, pluralizando a definição de políticas para além de apresentações e manifestações culturais, também importante para a valorização da cultura indígena, mas insuficientes para etnodemocratizar a democracia (ALBUQUERQUE, 2017, 2019).

As diretrizes, brevemente resumidas, apontam para iniciativas que alteram $o$ desenvolvimento de política estatal aos povos indígenas para uma política com os povos originários. Primeiramente devido a participação direta em todas as atividades públicas e privadas que possam impactar seus territórios e adjacências, posteriormente por uma nova articulação e construção de política indigenista pelo estado, e, finalmente, exigem o cumprimento de direitos já reconhecidos e a criação d'outros ainda inexistentes, numa perspectiva autonômica.

A correlação entre as deliberações dos espaços participativos com as proposições legislativas, a (in)congruência entre ambas, têm sido investigada por alguns estudiosos ${ }^{7}$ quanto a influência que a participação política exerce na representação. Para Pogrebinschi e Ventura (2017),

os dados e testes empíricos realizados mostram, de uma forma geral, que as CNPPs tornam o Congresso Nacional mais responsivo. Os espaços participativos permitem que os representantes eleitos por meio do voto conheçam mais e melhor

\footnotetext{
${ }^{7}$ URBINATI, Nadia. Representative Democracy: Principles and Genealogy. Chicago, Chicago University Press, 2006.; GURZA LAVALLE, Adrian; HOUTZAGER, Peter; CASTELLO, Graziella. "Democracia, Pluralização da Representação e Sociedade Civil". Lua Nova, n. 67, 2006, p. 49-103; CASTIGLIONE, Dario; WARREN, Mark. Rethinking Representation: Eight Theoretical Issues. Trabalho apresentado na Conference on Rethinking Democratic Representation, University of British Columbia, Vancouver, 18-19 de maio, 2006; AVRITZER, Leonardo. Experiências Nacionais de Participação Social. São Paulo: Cortez, 2010; AVRITZER, Leonardo; SOUZA, Clovis Henrique Lima (orgs.). Conferências Nacionais: Atores, Dinâmicas Participativas e Efetividade. Brasília, Ipea, 2013; DONAGHY, Maurren. Do Participatory Governance Institutions Matter? Municipal Councils and Social Housing Programs in Brazil”. Comparative Politics, vol. 44, 2011, pp. 83-102; POGREBINSCHI, Thamy; SANTOS, Fabiano. "Participação como Representação: O Impacto das Conferências Nacionais de Políticas Públicas no Congresso Nacional". DADOS, Revista de Ciências Sociais, vol. 54, n o 3, 2011, p. 259-305; POGREBINSCHI, Thamy; SAMUELS, David. The Impact of Participatory Democracy: Evidence from Brazil's National Public Policy Conferences. In: Comparative Politics. v. 46, n. 3, 2014; WAMPLER, Brian; TOUCHTON, Michael. "Improving Social Well-Being through New Democratic Institutions". Comparative Political Studies, vol. 47, n. 10, 2013; KATZ, Gabriel; MORLINO, Leonardo. What Qualities of Democracy in Latin America? Rome, 2013.
} 
as preferências da sociedade, aumentando as chances de formularem políticas que a contemple ou dela se aproxime. A constatação de que partidos de orientações ideológicas distintas convergem em torno da agenda de políticas demandada pela sociedade civil indica que inovações democráticas como as CNPPs têm potencial de somar representação e participação agregando mais qualidade à democracia. (POGREBINSCHI; VENTURA, 2017, p. 34)

O universo deste artigo se propõe tão-apenas a visibilizar a (in)adequação das proposições legislativas em relação às diretrizes dos povos originários na CNPI, considerando as variáveis congruência e incongruência quanto a receptividade pelo Legislativo das diretrizes indígenas.

\section{PROPOSIÇÕES NORMATIVAS SOBRE INDÍGENAS: O QUE NÃO QUER O EXECUTIVO E O LEGISLATIVO}

A busca por meio da ferramenta de "pesquisa avançada" no site da Câmara Federal, a partir do espaço "assunto"/“expressão textual”, com a palavra "indígenas", no período entre 05 de outubro de 1988 a 20 de abril de 2020, dos tipos de proposições "projetos de lei ordinárias (PLs)", "propostas de emenda à Constituição (PECs)", "projetos de lei complementar (PLPs)" e "medidas provisórias (MPVs)", retornou 240 proposições, algumas anteriores a 1988 e outras que adotaram o termo "indígena" apenas figurativamente, totalizando após essa filtragem 222 propostas das quais 154 PLs, 45 PECs, 19 PLPs e 04 MPVs.

A CNPI agregou um conjunto de demandas indígenas elaboradas e partilhadas em conferências anteriores, criando um acumulado de diretrizes consequentes da mobilização de lideranças desde a década de setenta (BICALHO, 2010; LACERDA, 2014). A avaliação temporal entre a criação de diretrizes e as proposições legislativas é desnecessária nesta pesquisa, porque já comprovada por Pogrebinschi e Ventura (2017) a relação crescente entre a formulação de proposições no Legislativo conforme aumenta a institucionalização das CNPPs.

Demandas criadas a partir de um processo político participativo tendem a influenciar as legislaturas, mas não é possível estabelecer se a proposição normativa foi criada devido a ocorrência desta ou daquela conferência, no mesmo ano ou em anos muito anteriores à apresentação na Câmara. Isto nada tem a dizer sobre a inexistência de relação entre participação e representação, mas da existência de dependência temporal entre elas. No conjunto de dados analisados por Pogrebinschi e Ventura (2017, p. 20) conseguiram demonstrar a existência de impacto crescente no Legislativo conforme se institucionaliza as CNPPs.

Se a dimensão temporal pode dizer algo sobre a influência das diretrizes no crescimento das proposições legislativas, a pertinência temática pode apontar sobre o seu conteúdo, pois as diretrizes podem ser avaliadas quanto a sua congruência $(+)$ ou incongruência (-) em relação ao assunto das proposições (justificativas no inteiro teor). Considera-se congruentes $(+)$ as proposições vinculadas ao sentido expresso nas diretrizes e categorias. Incongruentes (-) as proposições que contrariam ou alteram o sentido das diretrizes de modo integral ou parcial.

A importância de avaliar a associação de conteúdo entre as diretrizes e as proposições legislativas reside na afirmação da participação como variável a ser considerada na avaliação qualitativa da democracia (PATEMAN, 1970; MANSBRIDGE, 1983; WARREN, 2002; BARBER, 2004; GURZA LAVALLE, HOUTZAGERE, CASTELLO, 2006; FUNG, WRIGHT, 2003).

A dimensão participativa específica dos povos indígenas garante maior representatividade das preferências políticas multiculturais frente a política pública. As instituições que executam políticas públicas, ao considerar o termo "índio" desenvolve, por exemplo, cartilha de educação com ilustrações de um único povo (etnodemocratização homogênea) quando, na realidade, o país é pluriétnico com riquíssimo mosaico cultural a ser considerado a partir de múltiplos exemplos nas "cartilhas" ou com "cartilhas diferenciadas" (etnodemocratização pluralista). Aquela mais associada a afirmação da democracia e ampliação inclusiva de indígenas nas instituições, menos 
autonômica. Esta mais afeita à inclusão pluriétnica nas instituições, propensa a autodeterminar-se a partir das peculiaridades pluriétnicas indígenas, alterando o sentido homogêneo das políticas públicas indígenas. Ambas as dimensões são importantes no contexto indigenista brasileiro, pois existem níveis diferentes de relação dos povos indígenas entre si e entre a sociedade não-índia, mas condição fundamental reside na conquista e afirmação do território.

No quadro geral de correlação entre as diretrizes e as proposições legislativas tem-se um total de 222 proposições, das quais não ocorreu correlação com 05 categorias: "autonomia e direito à consulta e veto", "segurança alimentar", "assistência social", "direitos humanos - mulher, criança e adolescente" e "direitos humanos - direito à memória e à verdade". Das categorias correlacionadas a única que obteve diretrizes em todas as proposições foi "terras indígenas e territorialidade".

Figura 4 - Proposições legislativas por categorias da CNPI

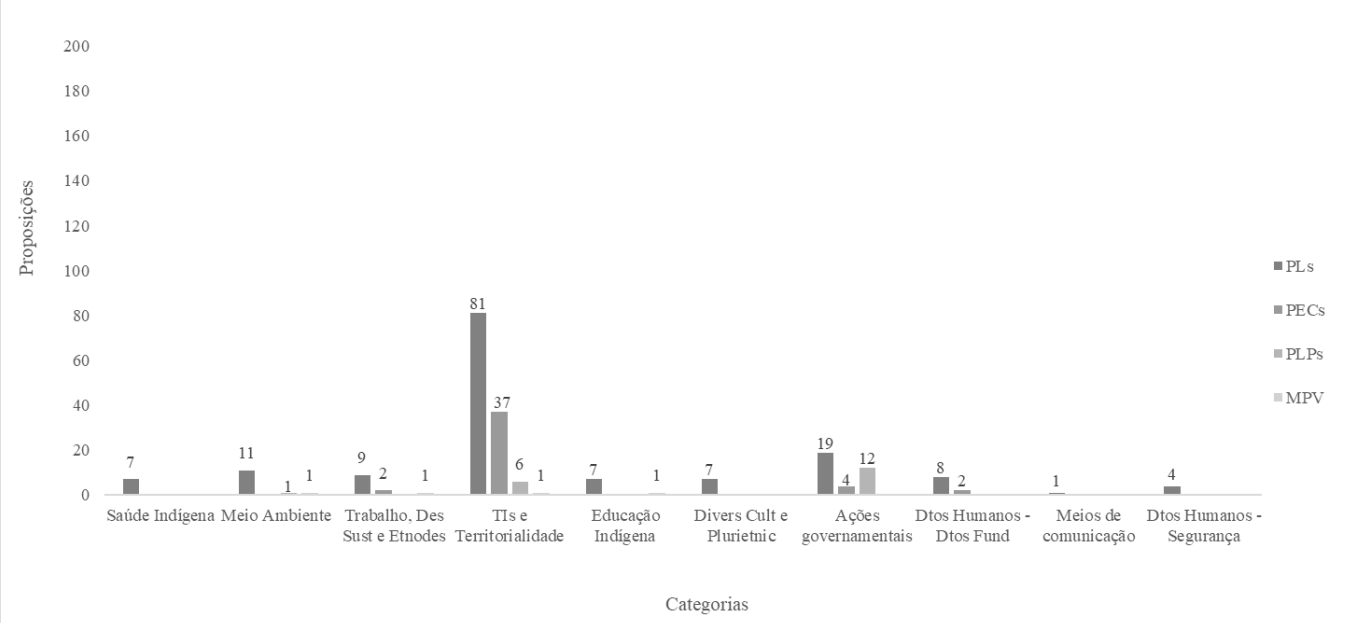

Fonte: BRASIL, 2020. BRASIL, 2016. Elaboração do Autor.

A análise da correlação entre as diretrizes e as proposições de leis recai sobre a congruência ou incongruência entre os assuntos das proposições com as diretrizes. Os assuntos correlacionados $^{8}$ apontam, para o processo legislativo, reivindicações que pluralizam as instituições democráticas, tanto no sentido etnodemocrático homogêneo como pluralista. Diferenciando as proposições entre as do poder executivo e do legislativo é possível apresentar maior ou menor congruência desses poderes às demandas da CNPI.

A análise sobre a maior ou menor congruência entre o conteúdo das diretrizes da CNPI e as proposições legislativas aponta maior ou menor aptidão das instituições desenvolverem ações indigenistas pluralizando a política pública. Quanto menor a pertinência temática entre as diretrizes e as proposições, maior a possibilidade de homogeneização de políticas públicas.

Das 222 proposições, 14 foram de iniciativa do executivo, 10 projetos de leis ordinárias e 04 medidas provisórias. Oito medidas foram transformadas em norma jurídica, 04 arquivadas, 01 está tramitando em conjunto e outra aguarda formação de comissão temporária. A Figura 5 apresenta a pertinência temática, congruência e incongruência, das proposições do executivo com as categorias das diretrizes indígenas.

\footnotetext{
${ }^{8}$ As iniciativas arquivadas seguem o regimento interno da Câmara que obriga o arquivamento de todas as proposições ao final da legislatura, e, posteriormente, por ocasião de reabertura das sessões, os(as) deputados(as) interessados(as) podem pedir o desarquivamento para a continuidade do trâmite.
} 
Figura 5 - Pertinência de proposições do executivo com as categorias da Conferência Nacional de Política Indigenista (CNPI)

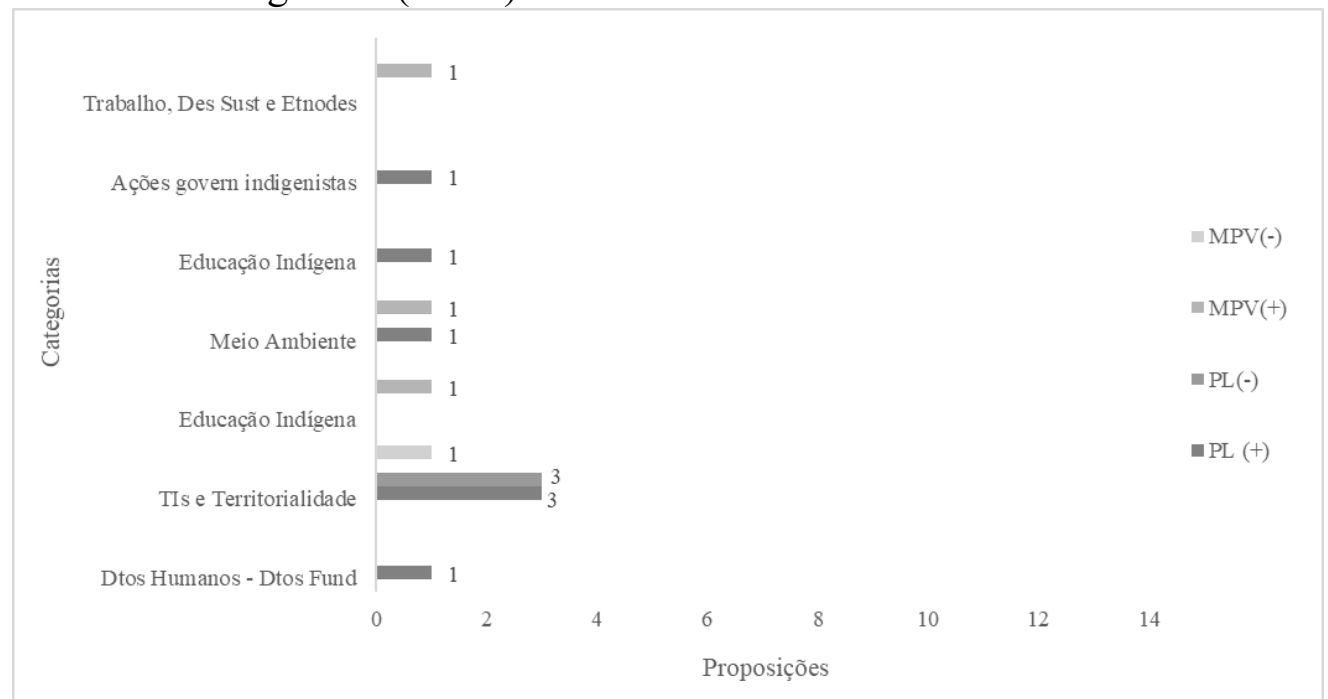

Fonte: BRASIL, 2020. BRASIL, 2016. Elaboração do Autor.

De um modo geral, os dados apresentam 10 proposições congruentes e 04 incongruentes. A maior inadequação de medidas do executivo reside sobre a categoria "TIs e Territorialidade", indicando dubiedade do estado, pois 3 projetos de leis congruentes e 3 incongruentes. Essa dubiedade já foi apontada por Perrone-Moisés (1992) ao analisar criticamente, em texto já clássico, a legislação indigenista vigente do século XVI ao XVIII.

Ao mesmo tempo que o estado se propõe a criar medidas congruentes aos anseios indígenas em relação aos seus territórios (devido às pressões e mobilizações indígenas) como, por exemplo, obrigar a averbação da TI na matrícula de propriedade se a área for localizada em domínio privado, garantindo que não possa ser "alienada" pelo proprietário, também tenta editar proposições para alterar a competência de demarcação da FUNAI para o MAPA, ou ainda, tenta autorizar a exploração de minérios em área indígena sem o devido esclarecimento, consentimento e participação dos povos originários.

Dentre as proposições congruentes, 03 foram arquivadas e 06 transformadas em normas jurídicas ${ }^{9}$. As congruentes associam-se aos governos FHC (2 medidas transformadas em norma), Itamar Franco (01 arquivada) e Lula (4 medidas transformadas em norma e 2 arquivadas), enquanto as incongruentes vinculam-se ao governo de Jair Bolsonaro, Fernando Collor de Melo e José Sarney. Durante o governo Dilma não consta proposições de autoria do executivo que tenham tramitado a partir do unitermo "indígenas".

\footnotetext{
${ }^{9}$ Provavelmente a menor aprovação de medidas incongruentes vincula-se à atenta observação de lideranças indígenas e suas associações (movimentos indígenas), bem como núcleos de pesquisa e entidades indigenistas, ao trâmite das proposições legislativas, deflagrando mobilizações (nacionais e internacionais) para impedir a criação de leis contra os anseios dos povos originários como, por exemplo, a atuação referente à PEC n. 215.
} 
Figura 6 - Pertinência temática das proposições legislativas do Poder Executivo com as demandas da CNPI (1988-2020)

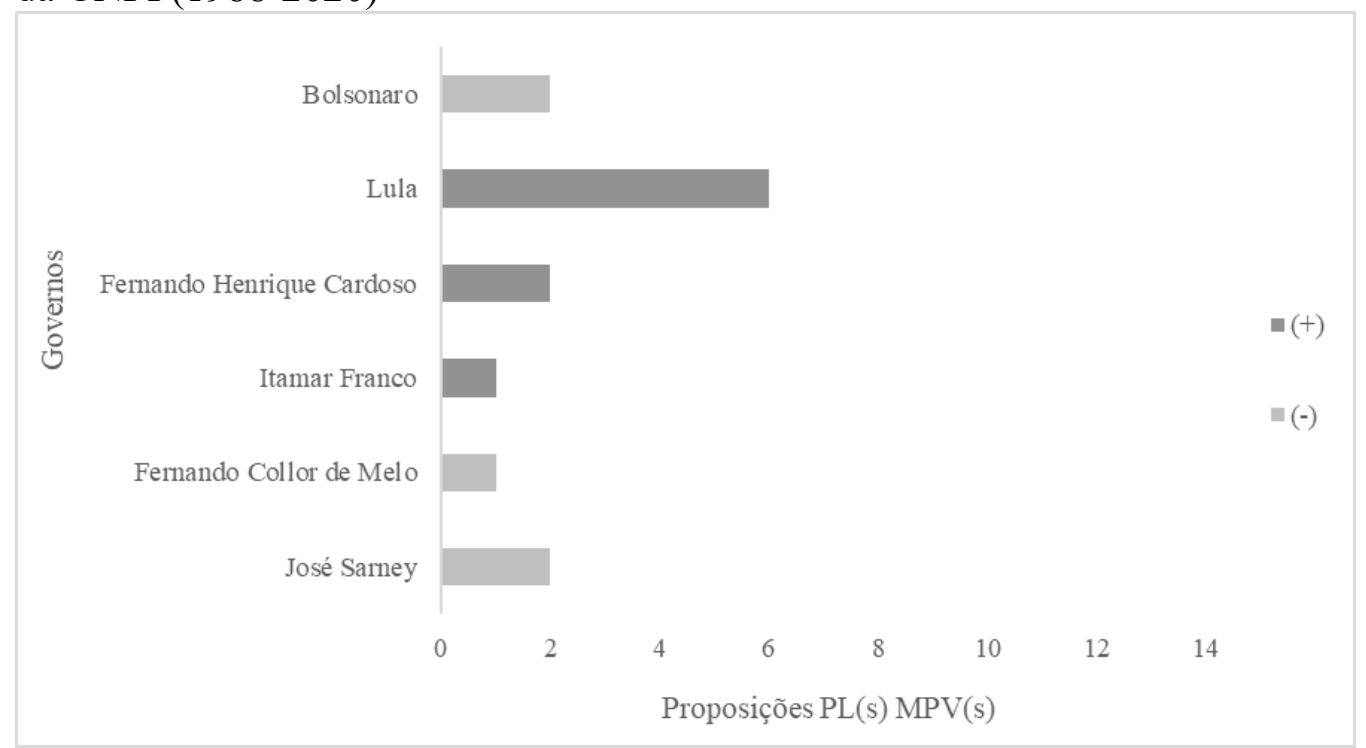

Fonte: BRASIL, 2020. Elaborado pelo Autor.

A variável ideologia partidária, com larga discussão na literatura política sobre partidos brasileiros ${ }^{10}$ (esquerda, centro e direita), pode ser avaliada para melhor alinhamento político entre os e dos povos indígenas, tanto para a urgente formação de um partido pluriétnico, como também para melhor se situarem ante os futuros pleitos eleitorais, assim como se posicionarem frente as forças políticas enquanto perdurar a subrepresentatividade eleitoral.

${ }^{10}$ ZUCCO JR., C. Esquerda, direita e governo: a ideologia dos partidos políticos brasileiros. POWER, T. J.; ZUCCO JR., C. (Ed.). O Congresso por ele mesmo: autopercepções da classe política brasileira. Belo Horizonte: Editora UFMG, 2011. p. 37-60. TAROUCO, G. D. S.; MADEIRA, R. M. Esquerda e direita no sistema partidário brasileiro: análise de conteúdo de documentos programáticos. Revista Debates, v. 7, n. 2, p. 93-114, 2013. SCHEEFFER, F. Ideologia e comportamento parlamentar na Câmara dos Deputados: faz sentido ainda falar em esquerda e direita? Orientador: Yan de Souza Carreirão. 2016. 291 f. Tese (Doutorado em Sociologia Política) - Programa de PósGraduação em Sociologia Política, Universidade Federal de Santa Catarina, Florianópolis, 2016. RODRIGUES, L. M. Partidos, ideologia e composição social: um estudo das bancadas partidárias na Câmara dos Deputados. São Paulo: Edusp, 2002. OTERO FELIPE, P.; ZEPEDA, J. A. R. Measuring political representation in Latin America: a study of the ideological congruence between parties and voters. American Political Science Association, Washington, p. 1-39, 2010. MAINWARING, S.; MENEGUELLO, R.; POWER, T. Partidos conservadores no Brasil contemporâneo: quais são, o que defendem, quais são suas bases. São Paulo: Paz e Terra, 2000. EPSTEIN, D. J. Clientelism Versus Ideology: Problems of Party Development in Brazil. Party Politics, v. 15, p. 335-355, 2009. DIAS, M. R.; MENEZES, D. B.; FERREIRA, G. da C. “A quem serve o Graal?". Um estudo sobre a classificação ideológica dos partidos políticos através de seus projetos de lei. Civitas, Porto Alegre, v. 12, n. 2, p. 209-235, maio/ago. 2012. LEONI, Eduardo. Ideologia, democracia e comportamento parlamentar: a Câmara dos Deputados (1991-1998). Dados - Revista de Ciências Sociais, Rio de Janeiro, v. 45, n. 3, p. 361 a 386, 2002. GIMENES, É. R. et al. Partidarismo no Brasil: análise longitudinal dos condicionantes da identificação partidária (2002-2014). Revista Debates, v. 10, n. 2, p. 121 -148, 2016. NICOLAU, J. M. Multipartidarismo e democracia: um estudo sobre sistema partidário brasileiro. Rio de Janeiro: FGV Editora, 1996. 
Figura 7 - Pertinência temática das proposições em relação aos partidos políticos

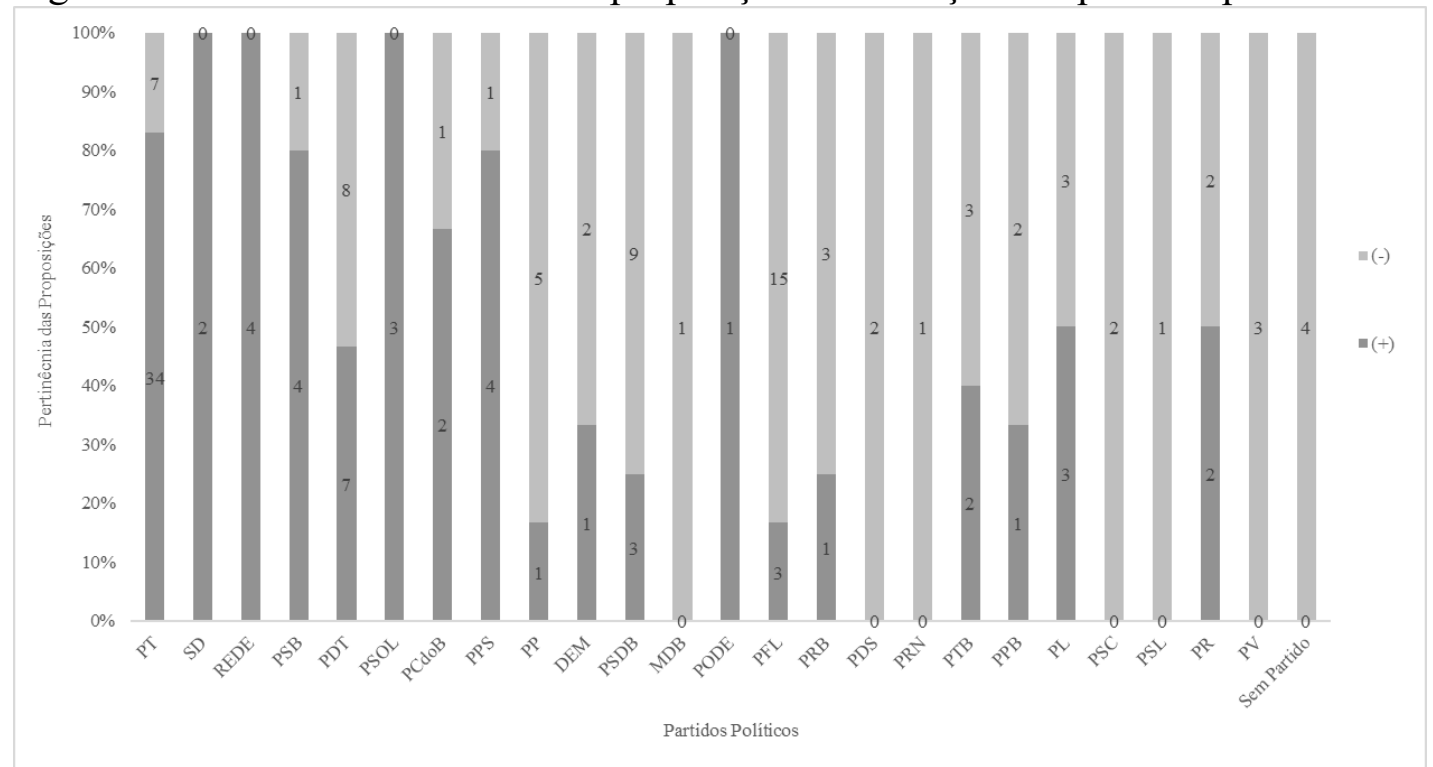

Fonte: Brasil, 2020. Elaborado pelo Autor.

Embora ausente o substrato teórico específico para discutir a classificação ideológica partidária brasileira - a ser elaborado noutro momento - os dados da Figura 7 apresentam maior congruência das iniciativas advindas dos partidos mais alinhados à esquerda e centro-esquerda $\mathrm{e}$ maior incongruência das proposições mais à direita e centro-direita. Corresponde aos dados da Figura 1, pois durante os governos Lula e Dilma ocorreram mais conferências e produções de diretrizes referentes aos povos indígenas que em outras gestões governamentais. Também confirma os estudos de Pogrebinschi e Ventura (2017), mas na dimensão de correlação entre os conteúdos das diretrizes e das proposições, cuja resposta confirma o aumento das proposições legislativas conforme se institucionalizam as CNPPs.

Por outro lado, os dados da Figura 7 não permitem confirmar, como apontam Pogrebinschi e Ventura (2017), a existência de convergência entre partidos políticos de orientações ideológicas distintas - ao menos quando se trata especificamente de assuntos indígenas - pois há grande concentração de propostas incongruentes no bloco de partidos de direita e centro-direita.

Em relação a pertinência temática dos PLs - ausente a variável partidos -, os dados indicam certa estabilidade quanto a congruência e a incongruência com a maioria das categorias da CNPI, apontando dubiedade do legislador no tratamento de medidas legislativas em relação aos povos indígenas. Exceção à regra reside na categoria "TIs e Territorialidades", pois o legislativo preponderantemente tem tentado criar várias medidas incongruentes às reivindicações indígenas. 
Figura 8 - Pertinência temática de PLs do Legislativo (1988-2020) correlacionados às categorias da CNPI

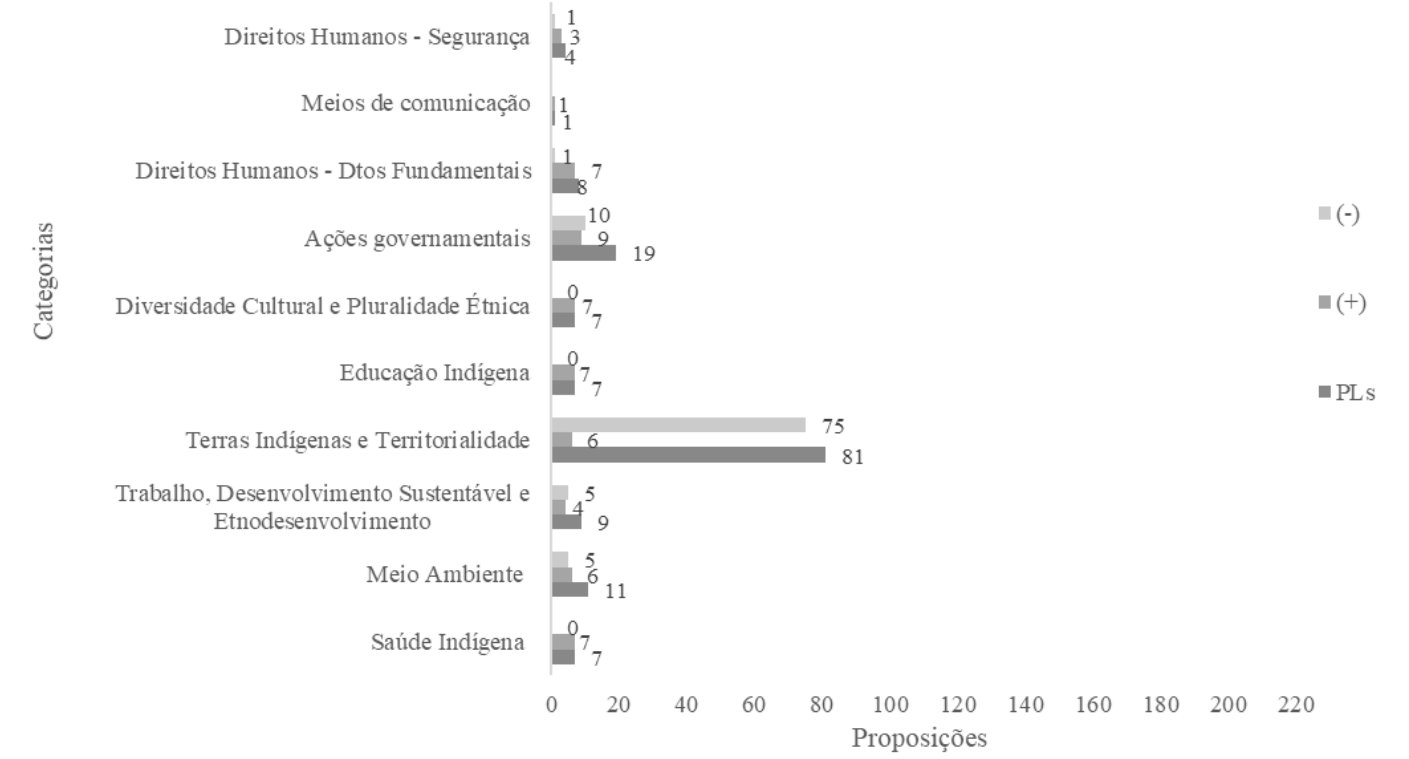

Fonte: BRASIL, 2020. BRASIL, 2016. Elaboração do Autor.

Dentre as principais incongruências nos 75 PLs do total de 81, analisados a partir das respectivas justificativas incluídas no inteiro teor das proposições, tem-se: a) restrições ao uso da terra enquanto não publicado o decreto homologatório das TIs, b) vedação de qualquer averbação sobre a demarcação de TI na matrícula da propriedade até a publicação do decreto homologatório; c) alteração da competência de demarcação das TIs da FUNAI para o Congresso Nacional, d) regulamentação da extração de recursos minerais fora do contexto do Estatuto dos Povos Indígenas e sem a anuência dos povos originários, e) indenização dos detentores de títulos de propriedades sobre as TIs.

Há pouca congruência entre as proposições do legislativo e as demandas dos povos indígenas quando se trata de TIs. Dentre as 06 proposições, por exemplo, tem-se: a) alteração do Estatuto do Índio para tipificar a intrusão em TIs (proposição retirada pelo autor), b) a criação de reserva do Fundo de Participação dos Municípios para município que possuam em seus territórios unidades de conservação da natureza ou TIs (arquivada), c) destinação de recursos para proteção da Amazônia.

A maioria dos representantes do congresso nacional estão não apenas dissociados da realidade indígena, mas pouco interessados em conhecê-la, além de contrários à demarcação e ampliação das terras aos povos originários, notadamente porque representam outros interesses. A maior representatividade reside em profissionais que comumente contrariam os interesses indígenas. O infográfico ${ }^{11}$ da Câmara quanto ao perfil da última legislatura é indubitável neste sentido, exceção à única deputada indígena eleita, Joênia Wapichana (REDE, Roraima, 20192023).

As proposições do tipo PLs e PECs possuem mais medidas incongruentes com as diretrizes, enquanto as LPPs e MPVs são mais congruentes, exceto a categoria "TIs e Territorialidade". Inexiste dubiedade de proposições no legislativo ao tratar de TIs, os parlamentares mais alinhados à direita e centro-direita são hegemonicamente contrários às reivindicações indígenas. A Tabela 2 apresenta a pertinência temática de atuação político-normativa

${ }^{11}$ Disponível em: $<$ http://www.camara.gov.br/internet/agencia/infograficoshtml5/composicaocamara2019/index.html>. Acesso: 20 abr. 2020. 
(Legislativo e Executivo) na criação de proposições legislativas sobre indígenas em relação às categorias da CNPI.

Tabela 2 Percentual (in)adequação entre as proposições (1988-2020) e as categorias

\begin{tabular}{|c|c|c|c|c|c|c|c|c|c|c|c|c|}
\hline Categorias da CNPI & PLs & $(+)$ & $(-)$ & PECs & $(+)$ & $(-)$ & PLPs & $(+)$ & $(-)$ & MPV & $(+)$ & $(-)$ \\
\hline $\begin{array}{l}\text { Trabalho, Desenvolvimento Sustentável e } \\
\text { Etnodesenvolvimento }\end{array}$ & 9 & 4 & 5 & 2 & 1 & 1 & 0 & 0 & 0 & 1 & 1 & 0 \\
\hline Terras Indígenas e Territorialidade & 81 & 6 & 75 & 37 & 4 & 33 & 6 & 2 & 4 & 1 & 0 & 1 \\
\hline Educação Indígena & 7 & 7 & 0 & 0 & 0 & 0 & 0 & 0 & 0 & 1 & 1 & 0 \\
\hline Diversidade Cultural e Pluralidade Étnica & 7 & 7 & 0 & 0 & 0 & 0 & 0 & 0 & 0 & 0 & 0 & 0 \\
\hline Ações governamentais & 19 & 9 & 10 & 4 & 2 & 2 & 12 & 11 & 1 & 0 & 0 & 0 \\
\hline Direitos Humanos - Segurança & 4 & 3 & 1 & 0 & 0 & 0 & 0 & 0 & 0 & 0 & 0 & 0 \\
\hline Total & 154 & 57 & 97 & 45 & 8 & 37 & 19 & 13 & 6 & 4 & 3 & 1 \\
\hline Percentual & $100 \%$ & $37,01 \%$ & $62,99 \%$ & $100,00 \%$ & $17,77 \%$ & $82,22 \%$ & $100 \%$ & $68,42 \%$ & $31,57 \%$ & $100 \%$ & $75 \%$ & $25 \%$ \\
\hline
\end{tabular}

Fonte: BRASIL, 2020; CNPI, 2016. Elaborado pelo Autor.

Predominantemente a incongruência entre as PECs e as diretrizes reside na tentativa, do legislativo e executivo (mais orientados à posição ideológica de direita e centro-direita), de alterar a competência para demarcação de TIs para o Congresso Nacional ou para o Ministério da Agricultura, Pecuária e Abastecimento (MAPA). Enquanto os assuntos congruentes (mais orientados à posição ideológica de esquerda e centro-esquerda) tratam desde a criação de vagas especiais na Câmara Federal para as comunidades indígenas, a destinação de percentagem de imposto sobre propaganda em televisão para os povos originários, até a proibição de ingresso de estrangeiros em TIs.

Em relação à "Saúde Indígena" os 07 PLs congruentes às demandas da CNPI relacionamse desde a regulamentação de mecanismos para a proteção, promoção, reconhecimento e exercício da medicina tradicional, das terapias complementares e do patrimônio biogenético das populações indígenas; às condições de funcionamento dos serviços de saúde aos povos indígenas, plano emergencial para enfrentamento ao coronavírus nas TIs, assegurando a garantia de direitos sociais e territoriais, bem como com medidas específicas de vigilância sanitária e epidemiológica para prevenção do contágio e da disseminação da COVID-19, até a inclusão dos povos originários nos programas de combate às neoplasias uterinas, mamárias e prostáticas no SUS.

As proposições sobre "Educação Indígena" são congruentes com as diretrizes ao tratarem de assuntos sobre a concessão de auxílio financeiro para assegurar a permanência dos estudantes indígenas de graduação em situação de vulnerabilidade socioeconômica, a criação de educação superior dos povos originários nas universidades públicas ou privadas ou criação de uma universidade indígena multicultural; reserva de vagas a candidatos autodeclarados indígenas nos concursos públicos para provimento de cargos do magistério público na educação básica, em locais com maior concentração de povos indígenas; a criação da Fundação Universidade Federal Autônoma dos Povos Indígenas.

Diversidade cultural e pluralidade étnica constitui-se de proposições congruentes, pois os assuntos ligam-se à reinvindicação de cooficialização de línguas indígenas em municípios com povos originários, a destinação de ao menos $40 \%$ (quarenta por cento) de recursos do Fundo Nacional de Cultura para projetos vinculados à cultura e à arte dos povos negros e indígenas, a regulação do uso de prenomes indígenas o registro civil, a criação de reserva de vagas no setor audiovisual para indígenas, em processos seletivos financiados com recursos públicos federais e a formação do Conselho Nacional de Direitos Indígenas.

A categoria ações governamentais comportou congruência com as proposições legislativas referentes à regulamentação do Estatuto dos Povos Indígenas, a criação de fundo para reassentamento de ocupantes de boa-fé retirados de TIs, a instituição de gratuidade nos transportes interestaduais para as populações indígenas, a reversão de benefício aos povos originários dos 
valores arrecadados em pagamento de multas por infração ambiental cometida em TIs, a inclusão de prioridade no Código de Processo Civil para a tramitação de processos de interesse dos povos indígenas.

As proposições incongruentes sobre ações governamentais indigenistas referem-se à retirada de prioridade na aquisição de gêneros alimentícios da agricultura familiar de assentamentos da reforma agrária, comunidades tradicionais indígenas e comunidades quilombolas, a criação de multa para a exploração e comercialização de bens localizados em áreas indígenas, a redefinição da competência e função da FUNAI e a criação de áreas livres para lazer e jogos.

A congruência entre os assuntos da categoria "Trabalho, Desenvolvimento Sustentável e Etnodesenvolvimento" estão associados às proposições que tratam desde instituir a Política Nacional de Energia Solar Fotovoltaica - PRONASOLAR, até a permissão aos povos indígenas para praticar atividades agropecuárias e florestais nas TIs, comercializar e gerenciar a produção da renda e a ampliação do limite de recursos financeiros utilizados na alimentação escolar com gêneros alimentícios originados das TIS dos povos originários. As medidas incongruentes referemse às perspectivas de desenvolvimento associadas, por exemplo, à implantação de cassinos nas TIs, a fixação de cota de parceria agrícola com os povos indígenas, a utilização do solo e dos recursos naturais nas TIs de modo sustentável e a permissão de atividades agrossilvipastoris em TIs.

A categoria meio ambiente é congruente com os assuntos das proposições quando se relacionam à instituir o sistema nacional de redução de emissões por desmatamento e degradação, conservação, manejo florestal sustentável, manutenção e aumento dos estoques de carbono florestal (REDD+), quando estabelecem distância mínima de $150 \mathrm{~km}$ para a implantação de indústrias emissoras de gases SO2, SO3 e NOx no entorno de unidades de conservação e em TIs, quando protegem o conhecimento tradicional associado aos recursos genéticos, incluindo tipificação penal em caso de utilização do patrimônio genético indígena, quando implementam a consulta prévia, livre e informada aos povos originários para emissão de licença ambiental para atividades ou empreendimentos que utilizam de recursos ambientais, efetiva ou potencialmente poluidores ou capazes, sob qualquer forma, de causar degradação ambiental. As proposições incongruentes relacionam-se à permissão de degradação ambiental em TIs, principalmente para exploração de recursos minerais desde que se apresente plano de recuperação da degradação.

A incongruência com a categoria "Direitos Humanos - Direitos Fundamentais" refere-se à proposição legislativa que visa criminalizar o infanticídio como prática tradicional cultural contrária aos povos originários ${ }^{12}$. Os assuntos congruentes estão associados desde a afirmação da identidade étnica no registro civil dos povos indígenas, o estabelecimento do direito de ir e vir em região de fronteira em época de paz, a priorização no Judiciário dos processos sobre demarcação de TIs.

Sobre a categoria "Meios de comunicação" a congruência refere-se à ampliação para os povos indígenas do direito de prestarem o serviço de radiodifusão comunitária.

Em relação aos "Direitos Humanos - segurança", congruentes são as matérias que tratam sobre a autorização de posse e porte de arma de fogo a membros de comunidades indígenas para proteção da TIs contra invasores, que versam sobre a formação de brigadas para combate a incêndios florestais, as que tornam hediondo o crime de homicídio, lesão corporal dolosa de natureza gravíssima e lesão corporal seguida de morte quando praticados contra indígenas. Incongruente é a proposição que objetiva criar nas TIs colônias penais agrícolas e industriais.

\footnotetext{
${ }^{12}$ Para maior aprofundamento ver CAMACHO, Wilsimara Almeida Barreto. "Infanticídio” indígena: um dilema entre a travessia e o permanecer à margem de si mesmo. 2011. 111f. Dissertação (Mestrado em Ciências Sociais). Universidade do Vale do Rio dos Sinos - Unisinos, São Leopoldo, 2011. RODRIGUES, Guilherme Scotti. Direitos fundamentais, eticidade reflexiva e multiculturalismo: uma contribuição para o debate sobre o infanticídio indígena no Brasil. 2011. 155f. Tese (Doutorado em Direito). Universidade de Brasília, Brasília, 2011. SILVEIRA, Mayra. O Infanticídio indígena: uma análise à luz da Doutrina da Proteção Integral. Florianópolis, 2011. 201f. Dissertação (Mestrado) - Universidade Federal de Santa Catarina, Centro de Ciências Jurídicas, Programa de Pós-Graduação em Direito, Florianópolis, 2011.
}

Revista de Direito Brasileira | Florianópolis, SC | v. 27 | n. 10 | p.374-397 | Set./Dez. 2020 
Muitas PLs, PECs e MPVs estão sendo criadas a fim de alterar a competência da demarcação de TIs para o Congresso Nacional ou para o MAPA, objetivando suprimir o direito constitucional dos povos indígenas a constituírem a posse tradicional sobre suas terras. Terra para as populações originárias é fonte de vida e riqueza para a própria subsistência de familiares e sustentabilidade ambiental, heranças a serem transmitidas para futuras gerações. A homologação de todas TIs é condição fundamental para o etnodesenvolvimento dos povos. A partir dela podem ser suscitados reconhecimento de direitos sonegados ou instituição de novos direitos.

Os dados apontam que tanto o executivo como o legislativo não pretendem satisfazer várias demandas indígenas, ao contrário, em relação às TIs, tanto não querem como manifestamente omitem e sonegam direito constitucionalmente reconhecido. Há ainda muitos PLPs para regulamentar direitos constitucionais indígenas suprimindo, por exemplo, a competência da FUNAI para outros órgãos federais. Enquanto os povos indígenas reivindicam a transformação da política indígena com a satisfação de direitos fundamentais e o reconhecimento de seus territórios e plurietnicidade, o Legislativo e o Executivo se propõem a criar propostas radicalmente contrárias às demandas indígenas. Os primeiros pleiteiam o direito à vida e a transformação, enquanto os segundos enunciam sonegação e regressão de direitos.

\section{CONCLUSÃO}

O artigo se propôs a levantar a correlação existente - quanto ao conteúdo associado ao unitermo "indígenas" - entre as demandas indígenas advindas do espaço participativo das conferências e as proposições legislativas junto à câmara federal.

Os dados apontam, para os povos indígenas, a necessidade de continuarem articulando suas posições participativas em confronto direto com as proposições em trâmite junto ao legislativo e executivo, mas também orientam para a criação de pautas de políticas públicas indígenas, fazendo uso da autonomia ratificada no decreto n. 5.051/2004, afirmando a plurietnicidade dos povos e, consequentemente, pautando as demandas legislativas e executivas pluriétnicas.

Embora ocorra correlação entre a ampliação de demandas da esfera participativa e o aumento de proposições legislativas, a sub-representação indígena exige articulação política de âmbito nacional que possa deflagrar maiores conquistas no espaço legislativo pelos próprios povos, ultrapassando as barreiras interétnicas e culturais entre povos diferenciados.

Também é possível afirmar que os dados a respeito das proposições legislativas apresentam maior congruência com as demandas quando iniciadas por partidos de orientação ideológica à esquerda e centro-esquerda que os partidos alinhados à direita e centro-direita.

Outro dado significativo reside na consolidação interétnica dos povos indígenas na defesa intransigente de seus territórios como, por exemplo, a união derredor à campanha "Demarcação Já!", evidenciando a superação de divisão entre povos com terras já homologadas e povos ainda a conquistarem suas terras. Há comunhão de esforços em prol da afirmação da demarcação e conquista de terras a todos os povos indígenas.

Caso atual, neste sentido, tem sido a atuação (no fechamento deste artigo) contra as ações governamentais que objetivam obstaculizar a demarcação de TIs como, por exemplo, a Instrução Normativa n. 9, de 27 de abril de 2020, da FUNAI, permitindo a ocupação por não-índios (proprietários particulares) de áreas ainda não homologadas, muito embora tais povos estejam efetivamente na posse de tais terras, aguardando continuidade dos procedimentos demarcatórios. Um grave ataque do governo federal, claramente anti-indigenista, aos direitos indígenas. Atos claramente de desterritorialização dos povos indígenas. Trata-se de medida inconstitucional a ser enfrentada pelos movimentos indígenas, Ministério Público Federal e entidades indigenistas.

Embora seja possível afirmar estar em curso um processo de etnodemocratização, o seu tipo é homogêneo, centrado na afirmação étnica comum de "povo indígena" e não povos a exigirem suas especificidades educacionais e de saúde, por exemplo. Ou seja, embora o processo de 
etnodemocratização em curso possa elevar a qualidade das instituições democráticas, tende a homogeneizá-la a partir de um sentido único de povo indígena e não de povos. Neste sentido, os dados não apontam demandas pluriétnicas para institucionalização, nos órgãos competentes, de uma ordem jurídica da diversidade cultural. Ademais, o processo etnodemocrático em andamento tem sofrido vários reveses ante a governança de Jair Bolsonaro, radicalmente refratário à conquista da terra pelos povos indígenas.

Permitem, os dados afirmar que em períodos políticos do governo Lula ocorreu maior participação indígena e menor retrocesso às garantias constitucionais indígenas, mesmo com o ideário de desenvolvimento dos Programas de Aceleração ao Crescimento (PACs). As proposições legislativas e executivas, durante este período possuem maior congruência com as demandas indígenas, demonstrando que os governos alinhados às posições ideológicas à esquerda e centroesquerda são mais propensos a formularem políticas públicas indigenistas e, portanto, ao processo de etnodemocratização no seu sentido homogêneo

As reivindicações de cooficialização das línguas indígenas nos municípios que possuem TIs constitui um caminho de etnodemocratização pluralista, exemplo de congruência entre o espaço participativo e a representação eleitoral. Do mesmo modo, elaborar proposição de ampliação da representação eleitoral que considere a plurietnicidade cultural - não apenas a partir do coeficiente demográfico dos indígenas em proporção aos eleitores não-indígenas - pode favorecer o debate político no âmbito da pluralidade interétnica.

A pluralização interétnica indígena na criação de política pública é caminho de maior etnodemocratização pluralista (heterogênea). Entretanto, sua implementação exige aos povos indígenas enfrentar obstáculos político-culturais complexos e ancestrais entre diferentes etnias, além do enfrentamento às medidas anti-indigenistas de governos radicalmente infensos aos direitos dos povos indígenas.

A coalizão de forças indígenas na defesa da territorialidade parece capaz de ultrapassar tais barreiras para afirmar maior interculturalidade e plurietnicidade a partir da densidade cultural plural, afirmando o consenso em torno do mosaico cultural brasileiro e, consequentemente, uma ordem jurídica da pluridiversidade.

\section{REFERÊNCIAS}

AVRITZER, L. National conferences in Brazil: a new participatory political model. Disponível em: <http://goo.gl/s1HnW>. Acesso: 19 mar. 2020.

BARBER, Benjamin. Strong Democracy. Participatory Politics for a New Age. Berkeley: University of California Press, 2004.

BICALHO, Poliene Soares dos Santos. Protagonismo indígena no Brasil: movimento, cidadania e direitos (1970-2009). Tese (Doutorado em História). Universidade de Brasília, Brasília, 2010, 464f.

BRASIL. Ministério da Justiça. Caderno de Propostas da I Conferência Nacional de Política Indigenista. Brasília: Ministério da Justiça, FUNAI, 2016.

BRASIL. Conferência Nacional Infanto-Juvenil pelo Meio Ambiente, 2018a.

BRASIL. $4^{\text {a }}$ Conferência Nacional de Promoção da Igualdade Racial, $2018 b$.

BRASIL. $1^{\text {a }}$ Conferência Nacional de Vigilância em Saúde, 2018c. 
BRASIL. $3^{\text {a }}$ Conferência Nacional da Educação, 2018d.

BRASIL. 16 ${ }^{\text {a }}$ Conferência Nacional de Saúde, 2019.

CAMERON, M. A., HERSHBERG, E., SHARPE, K. E. New Institutions for Participatory Democracy in Latin America: voice and consequence. New York: Palgrave Macmilla, 2012.

CUNHA, Manuela Carneiro da. Os direitos dos Índios. Ensaios. Documentos. São Paulo: Brasiliense, 1987.

DUPRAT, Deborah (Org.). Convenção n. 169 da OIT e os Estados Nacionais. Brasília: ESMPU, 2015.

FUNG, Archon; WRIGHT, Erik Olin. Deepening Democracy: Institutional Innovations. In Empowered Participatory Governance. London: Verso, 2003.

GURZA LAVALLE, Adrian; HOUTZAGER, Peter; CASTELLO, Graziella. "Democracia, Pluralização da Representação e Sociedade Civil”. In: Lua Nova, n. 67, 2006, p. 49-103.

INSTITUTO SOCIOAMBIENTAL. Situação atual das terras indígenas no Brasil. Disponível: $<$ https://terrasindigenas.org.br/>. Acesso: 08 abr. 2020.

LACERDA, R. F. "Volveré, y Seré Millones": Contribuições Descoloniais dos Movimentos Indígenas Latino Americanos para a Superação do Mito do Estado-Nação. v. I, II. 2014. 491f. Tese (Doutorado em Direito). Universidade de Brasília, Brasília, 2014.

ALBUQUERQUE, Antonio Armando Ulian do. Multiculturalismo e o direito de autodeterminação dos povos indígenas. v. I, II. 2003. 353f. Dissertação (Mestrado em Direito). Universidade Federal de Santa Catarina, Florianópolis, 2003.

ALBUQUERQUE, Antonio Armando Ulian do Lago. Multiculturalismo e direito à autodeterminação dos povos indígenas. Porto Alegre: Sérgio Antonio Fabris, 2008.

ALBUQUERQUE, Antonio Armando Ulian do Lago. Educação jurídica indígena. Curitiba: Juruá, 2016.

ALBUQUERQUE, Antonio Armando Ulian do Lago. "Comparação entre a participação indígena boliviana e brasileira: a inserção da atuação indígena brasileira no debate democrático e decolonial latino-americano". Rio de Janeiro: IESP-UERJ, 2017. 926f. Tese (Doutorado em Ciência Política) - Instituto de Estudos Sociais e Políticos, Universidade do Estado do Rio de Janeiro, Rio de Janeiro, 2017.

ALBUQUERQUE, Antonio Armando Ulian do Lago. Princípio constitucional da ecodignidade pluralista: breve introdução aos caracteres do processo de etnodemocratização. Revista de Direitos Fundamentais \& Democracia, v. 24, n. 1. Curitiba, 2019.

ALBUQUERQUE, Antonio Armando Ulian do Lago. Etnodemocracia brasileira: ampliação democrática do sistema representativo. In: Revista Amazônia Legal, v.6. Cuiabá: EdUFMT, 2015, p. 155-182. 
MANSBRIDGE, Jane. Beyond Adversary Democracy. Chicago: University of Chicago Press, 1983.

MCLAREN, Peter. Multiculturalismo crítico. São Paulo: Cortez, 1997.

PATEMAN, Carole. Participation and democratic theory. Cambridge University Press, 1970.

PERRONE-MOISÉS, Beatriz. Índios livres e índios escravos: os princípios da legislação indigenista do período colonial (séculos XVI a XVIII). In: História dos índios no Brasil, São Paulo: Cia das Letras, 1992, p. 116-132.

POGREBINSCHI, Thamy. Entre representação e participação: as conferências nacionais e o experimentalismo democrático brasileiro. Relatório Final da Pesquisa Brasília. Brasília: Ministério da Justiça (Série Pensando o Direito), 2010.

POGREBINSCHI, Thamy; SANTOS, Fabiano. "Participação como Representação: O Impacto das Conferências Nacionais de Políticas Públicas no Congresso Nacional”. Dados, Revista de Ciências Sociais, vol. 54, n o 3, 2011, p. 259-305.

POGREBINSCHI, Thamy; SAMUELS, David. The Impact of Participatory Democracy: Evidence from Brazil's National Public Policy Conferences. In: Comparative Politics. v. 46, n. 3 , 2014.

POGREBINSCHI, Thamy; VENTURA, Tiago. Mais participação, maior responsividade? As conferências nacionais de políticas públicas e a qualidade da democracia no Brasil. Dados, v. 60, n. 1, 2017, p. 7-43.

SANTOS, Sílvio Coelho dos. Povos indígenas e a Constituinte. Florianópolis: UFSC, Movimento, 1989.

TAROUCO, Gabriela da Silva. MADEIRA, Rafael Machado. "Partidos, programas e o debate sobre esquerda e direita no Brasil." In: Revista de Sociologia e Política. v. 21, n. 45, Curitiba, 2013, p. 149-165.

WARREN, Mark. "What Can Democratic Participation Mean Today?" Political Theory, vol. 30, n. 6, 2002, p. 677-701. 